\title{
The Real World of Arbitrariness Review
}

\section{Citation}

Cass Sunstein \& Thomas Miles, The Real World of Arbitrariness Review, 75 U. Chi. L. Rev. 761 (2008).

\section{Published Version}

http://www.law.uchicago.edu/files/files/368.pdf

\section{Permanent link}

http://nrs.harvard.edu/urn-3:HUL.InstRepos:10876006

\section{Terms of Use}

This article was downloaded from Harvard University's DASH repository, and is made available under the terms and conditions applicable to Open Access Policy Articles, as set forth at http:// nrs.harvard.edu/urn-3:HUL.InstRepos:dash.current.terms-of-use\#OAP

\section{Share Your Story}

The Harvard community has made this article openly available.

Please share how this access benefits you. Submit a story.

Accessibility 


\title{
CHICAGO
}

John M. Olin LAW \& ECONOMics WORKING PAPER No. 368

(2D SERIES)

Public LaW and Legal Theory Working Paper No. 188

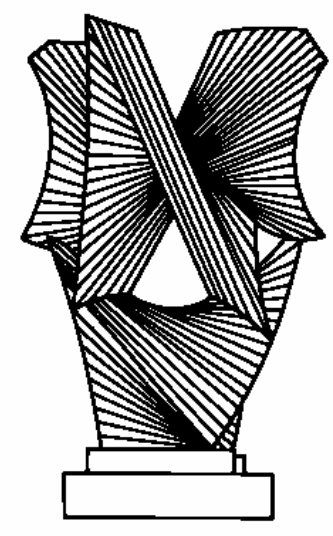

THE REAL WORLD OF ARBITRARINESS REVIEW

Thomas J.Miles and Cass R. Sunstein

\author{
THE LAW SCHOOL \\ THE UNIVERSITY OF CHICAGO
}

November 2007

This paper can be downloaded without charge at the John M. Olin Program in Law and Economics Working Paper Series: http://www.law.uchicago.edu/Lawecon/index.html and at the Public Law and Legal Theory Working Paper Series:

http://www.law.uchicago.edu/academics/publiclaw/index.html and The Social Science Research Network Electronic Paper Collection: http://ssrn.com/abstract_id=1028872 
Preliminary draft 10/10/07

Forthcoming U Chicago Law Review

All rights reserved

\title{
The Real World of Arbitrariness Review
}

\author{
Thomas J. Miles* and Cass R. Sunstein ${ }^{* *}$
}

\begin{abstract}
The Administrative Procedure Act instructs federal courts to invalidate agency decisions that are "arbitrary" or "capricious." In its 1983 decision in the State Farm case, the Supreme Court firmly endorsed the idea that arbitrariness review requires courts to take a "hard look" at agency decisions. The hard look doctrine has been defended as a second-best substitute for insistence on the original constitutional safeguards; close judicial scrutiny is said to discipline agency decisions and to constrain the illegitimate exercise of discretion. In the last two decades, however, hard look review has been challenged on the plausible but admittedly speculative ground that judges' policy preferences affect judicial decisions about whether agency decisions are "arbitrary." This study, based on an extensive data set, finds that the speculation is correct. Democratic appointees are far more likely to vote to invalidate, as arbitrary, conservative agency decisions than liberal agency decisions. Republican appointees are far more likely to invalidate, as arbitrary, liberal agency decisions than conservative agency decisions. Significant panel effects are also observed. Democratic appointees show especially liberal voting patterns on allDemocratic panels; Republican appointees show especially conservative voting patterns on allRepublican panels. Our central findings do not show that judicial votes are dominated by political considerations, but they do raise grave doubts about the claim that hard look review is operating as a neutral safeguard against the errors and biases of federal agencies. Because judicial policy commitments are playing a large role, there is a strong argument for reducing the role of those commitments, and perhaps for softening hard look review.
\end{abstract}

\footnotetext{
* Assistant Professor of Law, University of Chicago Law School.

** Karl N. Llewellyn Distinguished Service Professor, Law School and Department of Political Science, University of Chicago Law School. We thank Eric Posner, Richard Posner, Peter Strauss, and Adrian Vermeule for helpful comments. We are grateful to Rachael Dizard, Casey Fronk, Darius Horton, Matthew Johnson, Bryan Mulder, Brett Reynolds, Matthew Tokson, and Adam Wells for superb research assistance.
} 


\section{Introduction}

In the 1960s and 1970s, the federal courts of appeals, above all the United States Court of Appeals for the District of Columbia Circuit, developed the "hard look doctrine.” ${ }^{1}$ The doctrine found its origins in judicial decisions requiring administrative agencies to demonstrate that they had taken a "hard look" at the underlying questions of policy and fact. ${ }^{2}$ Hence agencies were required to offer detailed, even encyclopedic explanations for their conclusions; to respond to counterarguments; to justify departures from past practices; and to give careful consideration to alternatives to the proposed course of action. ${ }^{3}$ These were procedural requirements, to be sure, but they had significant effects, often shifting regulatory policy in identifiable directions by (for example) discouraging the approval of nuclear power plants ${ }^{4}$ and generally leading agencies to give heightened attention to environmental protection. ${ }^{5}$ Eventually courts went well beyond these procedural requirements to take a hard look on their own, assessing the reasonableness of the agency's judgments of policy and fact on their merits. ${ }^{6}$

The goal of hard look review was to police agency decisions for genuine arbitrariness, ${ }^{7}$ not to allow federal judges to impose their own policy preferences on the administrative state. Indeed, a central point of judicial review was to respond to the openended delegation of discretionary power by ensuring a firm check on agency decisions that might be "irrational or discriminatory." ${ }^{8}$ On this view, the hard look doctrine might be seen as a second-best substitute for the original constitutional safeguards against the uncontrolled exercise of discretion. Judicial scrutiny of agency judgments of policy and

\footnotetext{
${ }^{1}$ For an influential and well-known example, see Ethyl Corp v. EPA, 541 F2d 1 (DC Cir 1976)

${ }^{2}$ See Harold Leventhal, Environmental Decisionmaking and the Role of the Courts, 122 U Pa L Rev 509 (1974).

${ }^{3}$ All of these requirements can be found in Motor Vehicle Manufacturers Assn. v. State Farm Mutual Automobile Insurance Co., 463 US 29 (1983); in the same vein, see Corrosion Proof Fittings v. EPA, 947 F.2d 1201 ( $5^{\text {th }}$ Cir 1991).

${ }^{4}$ See Stephen Breyer, Vermont Yankee and the Courts’ Role in the Nuclear Energy Controversy, 91 Harv L Rev 1833 (1978).

${ }^{5}$ See William Pederson, Formal Records and Informal Rulemaking, 84 Yale LJ 59 (1975). For an early and illustrative signal of the intended effect of judicial review in the environmental domain, see Calvert Cliffs Coordinating Committee v AEC, 449 F.2d 1109 (DC Cir 1971).

${ }^{6}$ See, e.g., Citizens to Preserve Overton Park v Volpe, 401 US 402 (1971); Ethyl Corp v. EPA, 541 F2d 1 (DC Cir 1976) (en banc).

${ }^{7}$ See Citizens to Preserve Overton Park, 401 US at 406-410.

${ }^{8}$ See Ethyl Corp., 541 F.2d at 68 (Leventhal, J., concurring).
} 
fact might even serve as a method for reducing factional power over government, in a way that would recall longstanding concerns about the problems posed by the exercise of authority by self-interested private groups. ${ }^{9}$

As it developed, however, the hard look doctrine became highly controversial. ${ }^{10}$ Some of the controversy involved its likely effects. Would the doctrine discourage agency action altogether, and therefore freeze the status quo, rather than improving agency decisions ${ }^{11}$ ? Some of the controversy involved its legal foundations. Was hard look review an illegitimate creation of the federal courts ${ }^{12}$ ? What provision of law authorized federal judges to impose these various requirements on agencies, or to give careful scrutiny to the merits ${ }^{13}$ ? Independent questions lay in the background: Would judicial biases distort the inquiry into reasonableness ${ }^{14}$ ? Might judicial judgments reflect not an assessment of irrationality or discrimination, but the judges' own policy commitments?

In its seminal decision in Motor Vehicle Mfrs. Assn. v. State Farm Mutual Insurance Co., ${ }^{15}$ the Court entrenched hard look review and clarified its foundations. The Court rooted its analysis in section 702 of the Administrative Procedure Act, ${ }^{16}$ which requires courts to strike down agency action found to be "arbitrary" or "capricious."17 According to the Court, a decision would count as arbitrary if "the agency has relied on factors which Congress has not intended it to consider, entirely failed to consider an important aspect of the problem, offered an explanation for its decision that runs counter to the evidence before the agency, or is so implausible that it could not be ascribed to a difference in view or the product of agency expertise."18 These words, quoted hundreds

\footnotetext{
${ }^{9}$ See The Federalist No. 10 (Madison).

${ }^{10}$ See, e.g., Stephen Breyer, Judicial Review of Questions of Law and Fact, 38 Admin 1 Rev 363 (1986); Jerry Mashaw and David Harfst, The Challenge of Auto Safety (1985); Peter Strauss, Revisiting Overton Park, 39 UCLA L Rev 1251 (1992).

${ }^{11}$ See Mashaw and Harfst, supra note.

${ }^{12}$ For discussion, see Clark Byse, Vermont Yankee and the Evolution of Administrative Procedure: A Somewhat Different View, 91 Harv L Rev 1823 (1978).

${ }^{13}$ The question is raised in Vermont Yankee Nuclear Power Corp. v. NRDC, 435 US 519 (1978).

${ }^{14}$ See Ethyl Corp v. EPA, 541 F2d 1, 66-67 (DC Cir 1976) (Bazelon, J., concurring) (noting the risk that aggressive judicial review will "compound the error of the panel in making legislation policy determinations alien to its true function”).

${ }^{15} 463$ US 29 (1983).

${ }^{16} 5$ USC 702

${ }^{17}$ Id.

${ }^{18} \mathrm{Id}$. at 43.
} 
of times in federal court decisions, ${ }^{19}$ were widely taken to ratify both procedural and substantive components of the hard look doctrine. ${ }^{20}$

Many agency decisions, including those of the National Labor Relations Board, are subject to review as lacking "substantial evidence.” In its 1951 decision in Universal Camera, the Court emphasized that the substantial evidence test of the National Labor Relations $\mathrm{Act}^{21}$ and the Administration Procedure $\mathrm{Act}^{22}$ was “a response to pressures for stricter and more uniform practice," embodying a legislative "mood" in favor of increased judicial "responsibility for the reasonableness and fairness of Labor Board decisions. ${ }^{23}$ In practice, and especially in the aftermath of State Farm, review under the substantial evidence standard is probably the same as under the arbitrary and capricious standard, ${ }^{24}$ though it is sometimes thought that judicial review for substantial evidence is somewhat more searching. ${ }^{25}$

Since State Farm, the Court has issued no major pronouncements about judicial review of allegedly arbitrary agency action, and the doctrine has remained essentially stable for over two decades. ${ }^{26}$ But the controversies that preceded the decision have

\footnotetext{
${ }^{19}$ In fact these words have been quoted in no fewer than 572 cases as of April 23, 2007. LEXIS search, federal courts database, April 23, 2007.

${ }^{20}$ See Cass R. Sunstein, Deregulation and the Hard-Look Doctrine, 1983 Supreme Court Review 471.

${ }^{21} 29$ USC $160(\mathrm{e})$.

${ }^{22} 5$ USC 706(E).

${ }^{23}$ Universal Camera Corp. v. NLRB, 340 US 474 (1951).

${ }^{24}$ On the substantial evidence test, see Allentown Mack Sales and Service v NLRB, 522 US 359 (1998); Universal Camera Corp. v. NLRB, 340 US 474 (1951). Some provisions of the environmental statutes also call for substantial evidence review. The claim that there is no difference between the substantial evidence test and arbitrariness review is reflected in the fact that the legislative history of the statute in State Farm suggested that agency findings must be reviewed under the substantial evidence test. See 463 US at 39 (referring to substantial evidence test suggested by legislative history). By emphasizing the "arbitrary or capricious" test, the Court seemed to suggest that the substantial evidence test was essentially identical.

${ }^{25}$ State Farm is best taken as adopting the call for searching review issued long before in Citizens to Preserve Overton Park v. Volpe, 401 US 402 (1971).

${ }^{26}$ For a representatively minor pronouncement, at least on the general operation of arbitrariness review, see Verizon Communications v. FCC, 535 US 467 (2002). The most important ruling, involving substantial evidence review, may well be Allentown Mack Sales and Service v. NLRB, 522 US 359 (1998), which did seem to suggest an unusually aggressive approach; but that decision has not spurred significant rethinking in the lower courts.

The absence of a major ruling from the Court is itself something of a mystery. Why have we not seen large-scale developments from the Supreme Court in nearly a quarter-century? The answer may well lie in the fact that arbitrariness review is typically focused on specific questions of fact and policy, which makes Supreme Court review less likely, and which also makes Supreme Court rulings less likely to turn out to be broad pronouncements. We explore this point and its implications below.
} 
continued unabated. ${ }^{27}$ Some people object that the doctrine has unfortunate systemic effects on agency decisions. ${ }^{28}$ Others believe that the hard look is simply too hard and that a soft look would be much better. ${ }^{29}$ Still others fear that judicial biases play a large role in the operation of the hard look doctrine- that in finding inadequate explanations or unreasonableness on the merits, the policy preferences of judges are playing a substantial role. ${ }^{30}$ It is perhaps revealing here that State Farm itself, involving a high-profile initiative by the Reagan Administration, produced, on some key issues, what seemed to be a political division within the Court on the arbitrariness question, with conservative justices siding with the Reagan Administration. ${ }^{31}$ And other observers, most prominently Justice Breyer, object that there is an evident incongruity in the fact that under existing doctrine, courts often defer to agency interpretations of law, while taking a hard look at agency judgments about policy and fact. ${ }^{32}$

To date, only a sparse empirical literature exists on the actual operation of the hard look doctrine. ${ }^{33}$ There is no systematic evidence on the rate of invalidation under hard look review; we do not know if the rate is 10 percent, or 20 percent, or 40 percent. Nor is there evidence on the role, if any, of judicial policy preferences. Do Republican and Democratic appointees vote differently in cases involving hard look review? Are majority Republican panels different from majority Democratic panels, and if so, how different are they?

Our aim here is to begin to fill this gap. We do so through an analysis of a large data set, consisting of all published appellate rulings from 1996 to 2006 involving review of decisions of the Environmental Protection Agency (EPA) and review of National

\footnotetext{
${ }^{27}$ Though the central issues involved statutory interpretation rather than arbitrariness, the Court's decision in Mass. v. EPA, 549 US, (2007), might well be taken as a modern version of State Farm, also involving a "hard look." For a valuable discussion to this effect, see Jody Freeman and Adrian Vermeule, Massachusetts v. EPA: From Politics to Expertise, Supreme Court Review (forthcoming).

${ }^{28}$ See, e.g., Mashaw and Harfst, supra note (contending that hard look review leads agencies to avoid rulemaking).

${ }^{29}$ See Richard Pierce, Seven Ways to Deossify Agency Rulemaking, 47 Admin L Rev 59 (1995).

${ }^{30}$ See R. Shep Melnick, Regulation and the Courts: The Case of the Clean Air Act (1983).

${ }^{31}$ Compare 463 US at (invalidating, as arbitrary, agency decision with respect to detachable and nondetachable belts) with id at (Rehnquist, J., concurring in part and dissenting in part) (arguing that decision on these points was not arbitrary).

${ }^{32}$ See Breyer, supra note.

${ }^{33}$ The principal exceptions are Richard Revesz, Environmental Regulation, Ideology, and the DC Circuit, 83 Va L Rev 1717 (1997), Joseph L. Smith and Emerson H. Tiller, The Strategy of Judging: Evidence from Administrative Law, 31 J Leg Stud 61 (2002) (presenting evidence that strategic reasons motivate judges' choice of Chevron and State Farm as the basis for their decisions).
} 
Labor Relations Board (NLRB) decisions either for arbitrariness or for lack of substantial evidence. ${ }^{34}$ (For convenience, we use the phrase "arbitrariness review" to capture the relevant test, which does not seem to differ significantly across the two contexts. ${ }^{35}$ ) Use of this data set has several advantages. First, both the agency and judicial decisions are fairly easy to code in political terms, and hence it is possible to test competing hypothesis about the role of judicial ideology. ${ }^{36}$ Second, EPA and NLRB decisions are extremely important in their own right, and they also provide a good "snapshot" of the world of arbitrariness review. ${ }^{37}$ Third, there is a large data set, in essentially the same period, involving judicial review of interpretations of law by the EPA and the NLRB. ${ }^{38}$ An examination of arbitrariness review permits instructive comparisons. ${ }^{39}$ Fourth, the EPA is an executive agency, whose head is an at-will employee of the president, whereas the NLRB is an independent agency, whose chair and majority are determined by the incumbent president but whose members may be discharged only for cause (and therefore have, in practice, a form of tenure). Hence our data set includes two of the most prominent agencies, one of which has the "executive agency" form and the other of which has the "independent agency" form. ${ }^{40}$

The central goal of arbitrariness review is to filter out serious errors of analysis, not to encode judicial policy preferences, and we are interested above all in testing whether courts are carrying out that task. Much of the debate in modern administrative law is about that question, ${ }^{41}$ which has yet to be tested. If Democratic and Republican

\footnotetext{
${ }^{34}$ On arbitrariness review and the NLRB, see note infra.

${ }^{35}$ See note

${ }^{36}$ This task is far more difficult for such agencies as the Federal Communications Commission and the Securities and Exchange Commission, where political coding can be quite contentious. We have, however, compiled a data set of all cases citing State Farm, offering some preliminary conclusions about validation rates; the data are available on request.

${ }^{37}$ Of course we cannot exclude the possibility that the patterns we observe are different for other agencies.

${ }^{38}$ See Thomas J. Miles and Cass R. Sunstein, Do Federal Judges Make Regulatory Policy? An Emprical Analysis of Chevron, 73 U Chi L Rev 823 (2006).

${ }^{39}$ The data set for Chevron cases extends across a larger time period, but we find consistent results across time in those cases, and hence the comparison holds.

${ }^{40}$ While our focus is on the period 1996-2006, it is entirely imaginable that similar patterns would be found in similar periods, including those preceding State Farm. We would not be at all surprised, for example, if in review of NLRB cases between 1956 and 1966, broadly similar patterns might be found. Prior research on how administrative agencies fare before the Supreme Court reveals that their success rates vary across substantially across agencies, but that overall agencies' success rates are generally stable over time. See note 83 , infra. It would be most interesting, however, to examine directly how the patterns we discern change, if at all, over time.

${ }^{41}$ See, e.g., Melnick, supra note; Breyer, supra note.
} 
appointees show significantly different rates of "liberal voting" in cases reviewing agency decisions for arbitrariness review, there is evident reason for concern. And if allDemocratic panels show dramatically different voting patterns from all-Republican panels, there is reason to believe that similarly situated litigants are not being treated similarly, in a way that has serious consequences for regulatory policy and even the rule of law.

In brief, our principal findings are as follows.

1. Political commitments significantly influence the operation of hard look review in EPA and NLRB cases. When the agency decision is liberal, the Democratic validation rate is $71 \%$ and the Republican validation rate is $56 \%$. When the agency decision is conservative, the Democratic validation rate drops to $58 \%$ and the Republican validation rate rises to $72 \%$. For both Republican and Democratic appointees, then, the likelihood of a vote to validate is significantly affected by whether the agency's decision is liberal or conservative.

2. In an important sense, these figures understate the role of ideology in hard-look review, because panel effects are substantial. Democratic appointees show higher liberal voting rates $(71 \%)$ when sitting with two other Democratic appointees. Republican appointees show lower liberal voting rates (49\%) when sitting with two other Republican appointees. The resulting difference between the two sets of appointees-22\% - has large consequences for the real world of administrative law.

3. For the EPA and the NLRB cases, taken together, the overall rate of votes to validate agency decisions challenged as arbitrary is 64\%. Notably, the rate of validation votes is significantly higher for Democratic appointees than for Republican appointees: 69\% for Democratic appointees and 60\% for Republican appointees. Strikingly, the rate of validation is essentially the same in arbitrariness review as in Chevron cases - a finding that casts doubt on Justice Breyer's suggestion that courts might be giving greater scrutiny to agency judgments of fact than to agency judgments of law. ${ }^{42}$

In general, we provide significant evidence of a role for judicial ideology in judicial review of agency decisions for arbitrariness. The goal of the "arbitrary or capricious” standard is to ensure that judges invalidate agency actions when those actions reflect serious analytic errors or palpable political pressures, and to prevent these errors and pressures from being translated into grounds for law. ${ }^{43}$ Most ambitiously, arbitrariness review can be seen as a response to the uneasy constitutional position of agencies wielding broad discretionary power; perhaps such review can reintroduce

\footnotetext{
${ }^{42}$ See Breyer, supra note.

${ }^{43}$ See Merrick Garland, Deregulation and Judicial Review, 98 Harv L Rev 505 (1988).
} 
surrogate safeguards for the decline of constitutional checks on agency authority. But if Democratic appointees are especially inclined to find conservative decisions to be arbitrary, and if Republican appointees are especially likely to find liberal decisions to be arbitrary, something is seriously amiss.

Notably, the role of political judgments appears to be strikingly similar when courts are reviewing agency interpretations of law under Chevron and when judges are addressing questions of fact and policy under arbitrariness review. The numbers are very close in the two contexts. This finding suggests that at least in the domain of EPA and NLRB decisions, ideology influences judges' decisionmaking to the same extent regardless of the judicial task or the standard of review. Moreover, the degree of ideological influence seems roughly the same for both tasks and under both standards.

Our findings offer a clear prediction for the future: When a judiciary consisting mostly of Democratic appointees confronts a conservative executive branch, the rate of invalidations will be unusually high, and so too when a judiciary consisting mostly of Republican appointees confronts a liberal executive branch. The conflict between (for example) a Democratic administration and a Republican-dominated judicial branch should be expected to produce a large number of invalidations in the most important domains of regulatory policy. Notably, such invalidations will typically involve complex questions of law and fact, not readily suited to oversight by the Supreme Court. We will

offer some suggestions about how existing doctrines might change to counteract the evident risks.

\section{Administrative Law Preliminaries}

To understand our study, some background is in order. Agency decisions might be challenged on many possible grounds. Most obviously, their decisions might violate a governing statute. With respect to such challenges, much of current doctrine is organized under the framework established by the Court's Chevron decision. ${ }^{44}$ That decision provides a famous two-step test for evaluating agency interpretations of law. The first question is whether the agency has violated an unambiguous provision of law. If not, the court proceeds to the second question, which is whether the agency's interpretation of an

${ }^{44}$ Chevron, Inc. v. NRDC, 467 US 837, 842-44 (1984). 
ambiguous provision is reasonable..$^{45}$ But many agency interpretations are not entitled to judicial deference under Chevron, and such interpretations will receive less deference, or even no deference, from reviewing courts. ${ }^{46}$ We are not concerned with agency interpretations of law here, except by way of comparison.

Agency decisions might also be challenged as inconsistent with the procedural requirements of the Administrative Procedure Act (APA) ${ }^{47}$ or any other applicable statute. For example, the agency might have issued a rule without using notice-andcomment procedures, ${ }^{48}$ or it might have violated a statutory prohibition on ex parte communications. ${ }^{49}$ Judicial review of agency compliance with the APA's procedural requirements raises many important questions, and an empirical study of the relevant judicial decisions would undoubtedly be instructive. Perhaps ideological voting can be found in this domain as well. Might Democratic appointees be comparatively willing to find violations of the procedural requirements of the APA when the agency has issued a conservative rule? Might Republican appointees to more willing to invalidate agency decisions on procedural grounds when those decisions turn out to be liberal? We suspect so, and it would be valuable to know; but we do not explore such issues here.

Our focus is on the question whether agency decisions are unlawful because arbitrary or lacking substantial evidence. That question might be understood as a kind of Step 3, to be asked directly after the two-step inquiry mandated by Chevron. To understand that question, it is necessary to explore the hard look doctrine and State Farm in somewhat more detail. The case itself involved an important controversy over the legal validity of a change in regulatory policy initiated by the Reagan Administration. Under President Carter, the National Highway Traffic Safety Administration (NHTSA) had shown considerable interest in "passive restraints," in the form of automatic seatbelts or airbags, which would protect drivers even if they failed to take action to buckle up. ${ }^{50}$ The ultimate regulation, issued in the closing months of the Carter Administration, required automobile manufacturers to equip new cars with one of three possible passive restraints:

\footnotetext{
${ }^{45}$ Id. at $843-44$.

${ }^{46}$ See US v. Mead Corp, 533 US 218 (2001); Cass R. Sunstein, Chevron Step Zero, 92 Va L Rev. 187 (2006). 
detachable seatbelts; nondetachable seatbelts; or airbags. ${ }^{51}$ NHTSA concluded that the new rule would produce at least a $13 \%$ increase in seatbelt usage, and that as a result, its benefits would justify its costs. ${ }^{52}$

Within six months, President Reagan’s NHTSA repealed the regulation. ${ }^{53}$ In brief, the agency concluded that contrary to the analysis under President Carter, the regulation would not produce a significant increase in seatbelt usage, and hence the benefits were too uncertain to justify the imposition of the passive restraints rule on manufacturers. ${ }^{54}$ This conclusion was challenged as arbitrary; the challengers invoked the hard look doctrine. The government responded quite ambitiously, by attacking that doctrine as illegitimate; in its view, agency action must be upheld unless it was wholly irrational, in a highly deferential analysis similar to that undertaken under the due process clause. ${ }^{55}$ Notwithstanding its ambition, this argument did not seem implausible in light of the Court's then-recent decision in Vermont Yankee, ${ }^{56}$ which emphasized that judges had no business burdening agencies with duties that could not be found in the Administrative Procedure Act or some other source of law. ${ }^{57}$ Moreover, the government's objection to the hard look doctrine could draw strength from the view, pressed by many skeptics in the period, that liberal judges had used the doctrine so as to push regulatory policies in the directions that they themselves favored on the merits. ${ }^{58}$

In striking down the repeal of the regulation, the Court endorsed both procedural and substantive aspects of the hard look doctrine. ${ }^{59}$ Speaking in general terms, the Court unanimously said that the agency must provide a detailed explanation of agency action, offer careful attention to counterarguments, and show serious engagement with alternatives. ${ }^{60}$ On the merits, the Court concluded, again by a unanimous vote, that the repeal of the regulation was arbitrary because NHTSA had not investigated whether an

\footnotetext{
${ }^{51}$ Id. at 37-38.

52 Id. at 51-55.

${ }^{53}$ Id at 38-40.

54 Id. at 54-55.

55 See id at 44 n. 9.

${ }^{56}$ Vermont Yankee Nuclear Power Corp. v. NRDC, 435 US 519 (1978).

${ }^{57}$ Id. at 550-551.

${ }^{58}$ See, e.g., R. Shep Melnick, Regulation and the Courts (1983).

59463 US at 47-50.

${ }^{60}$ Id. at $48-51$.
} 
"airbags only" alternative would have produced sufficient benefits to justify the rule. ${ }^{61}$ By a vote of 5-4, the Court also held that the agency's analysis of detachable and nondetachable belts was arbitrary, because it depended on unsupported judgments about likely facts. ${ }^{62}$

The 5-4 division within the Court is especially noteworthy for our purposes, for it occurred along evidently political lines. The dissenting opinion was written by thenJustice Rehnquist, who emphasized that it was entirely appropriate for President Reagan to reject the policies of his predecessor. ${ }^{63}$ In his words, "[t]he agency's changed view of the standard seems to be related to the election of a new President of a different political party.... A change in administration brought about by the people casting their votes is a perfectly reasonable basis for an executive agency's reappraisal of the costs and benefits of its programs and regulations." ${ }^{\text {64 }}$ Thus Justice Rehnquist offered a firm plea for judicial deference in the face of the new commitments of a new administration-a plea that bears directly on the data that we shall offer here.

State Farm was widely taken to have ratified the hard look doctrine. ${ }^{65}$ The Court's description of the appropriate standard of review, and its conclusions on the merits, suggested that courts should require detailed justifications for an agency action and also examine the reasonableness of the agency's conclusions. There was obvious tension, however, between State Farm and Chevron, decided just one year later. ${ }^{66}$ Under State Farm, courts would take a hard look at agency judgments of policy and fact; under Chevron, courts would give considerable deference to agency interpretations of ambiguous statutes. Hence it was natural to object, as did then-Judge Breyer, that a sensible system of judicial review would not entitle courts to give careful scrutiny to judgments of policy and fact while also requiring them to defer on questions of law. ${ }^{67}$ If we attend to the distinctive competence of agencies and courts, the opposite conclusion might seem hard to resist: Questions of law are for judicial resolution, whereas questions of policy and fact should be resolved by agencies.

\footnotetext{
${ }^{61} \mathrm{Id}$ at $48-49$.

${ }^{62}$ Id. at $51-55$.

${ }^{63}$ Id. at 59 (Rehnquist, J., concurring in part and dissenting in part).

${ }^{64}$ Id.

${ }^{65}$ See, e.g., Sunstein, supra note.

${ }^{66}$ See Breyer, supra note.

${ }^{67}$ See id.
} 
But this simple comparison between State Farm and Chevron misses some complexities. First, it may not be correct to suggest that the former decision suggests “less” deference than the former. Under Chevron, agencies must obey unambiguous statutes, ${ }^{68}$ and even when there is ambiguity, agency interpretations must be reasonable. ${ }^{69}$ Under State Farm, agency decisions will also be upheld so long as they are reasonable. ${ }^{70}$ In the abstract, it would be possible to read the two rulings in a way that would not create the anomaly to which Justice Breyer objects. In any case it is much too simple to suggest that courts should decide questions of law on their own. ${ }^{71}$ Where statutes are ambiguous, the resolution of the ambiguity frequently requires judgments of policy and principle. Chevron rests on the belief that such judgments should be made by officials with a degree of accountability and specialized competence, not by judges. ${ }^{72}$

But if this point is correct, State Farm itself must be taken with a degree of caution. Review of agency decisions for arbitrariness often involves highly technical issues of policy and fact, and rulings by courts of appeals are usually too particularistic to be well-suited to Supreme Court review. If State Farm is operating in a way that reflects judicial policy preferences, Justice Breyer’s objection has considerable force.

The empirical questions emerge as the important ones. What, exactly, have appellate courts ${ }^{73}$ been doing? What might be said about the real world of arbitrariness review? It is to these questions that we now turn.

\section{Arbitrariness Review of EPA and NLRB Decisions in the Courts of Appeals}

\section{A. Data and Method}

We devote our attention to two agencies whose decisions have a high degree of practical importance and political salience, the Environmental Protection Agency (EPA)

\footnotetext{
${ }^{68}$ See, e.g., Public Citizen v Young, 831 F2d 1108 (DC Cir 1997).

${ }^{69}$ See, e.g., Ohio v. Dept of Interior, 880 F2d 432 (DC Cir 1989).

${ }^{70}$ See, e.g., Syracuse Peace Council v. FCC, 867 F2d 654 (DC Cir 1989).

${ }^{71}$ See, e.g., Antonin Scalia, Judicial Deference to Agency Interpretations of Law, 1989 Duke LJ 511; E. Donald Elliott, Chevron Matters, 16 Vill Env LJ 1 (2005).

${ }^{72}$ See Cass R. Sunstein, Beyond Marbury: The Executive’s Power to Say What the Law Is, 115 Yale LJ 2580 (2006).

${ }^{73}$ We put decisions by the Supreme Court to one side, on the ground that the Court has decided very few cases involving "arbitrary or capricious" review, and hence no results would have statistical power.
} 
and the National Labor Relations Board (NLRB). ${ }^{74}$ We extracted from the standard legal databases a list of appellate court cases that applied arbitrary and capricious or substantial evidence review to decisions of the EPA and NLRB ${ }^{75}$ between 1996 and 2006. There were 653 cases in all, and a strong majority of these cases, 607, reviewed NLRB decisions. It would be natural to think that in view of these numbers, our focus is necessarily on review of NLRB decisions, but most of the patterns do not significantly differ as between review of EPA decisions and review of NLRB decisions. Where the differences are significant, we report them. (Our strong suspicion is that the same general patterns would be found for other agencies, but that point must remain speculative for now.) We coded the votes of the individual judges in these cases and assembled a file of judge-by-case observations. Of the 1,959 total votes by judges in these cases, 861 were votes by appointees of Democratic presidents and 1,098 were votes of appointees of Republican presidents.

For all of the key questions, illuminating patterns emerge, allowing us to assess party and panel effects in arbitrariness review. We are also able to disaggregate the data in such a way as to cast light on questions that have been explored in the literature on both arbitrariness review and judicial behavior under Chevron. ${ }^{76}$

To test the role of judicial policy judgments, we use several interacting measures. For judges, we focus on the party of the appointing president, because that factor has importance in its own right and because it serves as a rough proxy for the ideological preferences of the judges. To say the least, it would be valuable to know if Democratic appointees are especially likely to find arbitrariness on the part of Republican administrations, or if the validation rates of Republican appointees increase when the president is a Republican. Although political scientists have legitimately criticized the use

\footnotetext{
${ }^{74}$ A valuable discussion of judicial review of NLRB decisions, involving a different data set and somewhat different questions but overlapping conclusions, is James Brudney et al., Judicial Hostility Toward Labor Unions? Applying the Social Background Model to a Celebrated Concern, 60 Ohio LJ 1675 (1999).

${ }^{75}$ See note supra.

${ }^{76}$ We conducted regression analysis to verify the robustness of our findings to other possible influences on a judge's review of an arbitrariness challenge. In addition to the variables described in this Sections III and IV, the regressions included fixed effect controls for circuits and years. The regression analysis did not alter the conclusions we reached from examining summary statistics, and therefore, we omit the regressions from our discussion here.
} 
of party as a proxy for political ideology ${ }^{77}$ and often use “common space scores” as an alternate measure, ${ }^{78}$ the political party of the appointing president remains a valuable tool of inquiry, ${ }^{79}$ especially for those interested in the power of the executive to move the federal judiciary in its preferred directions.

We measure the political content of the agency decisions in two distinct ways. First, we classify agency differences as "conservative" or "liberal" on the basis of the identity of the party making the challenge. When a labor union or public interest group challenges an agency decision, we deem it to be relevantly "conservative." When an industry group or corporation challenges the agency's decision, we code it as relevantly "liberal." The reason for this approach is that the reviewing court assesses the position of an agency not in the abstract, but in relation to the claims of the particular challenger. When a public interest group, such as the Sierra Club or the Natural Resources Defense Council, brings a challenge, the agency appears conservative relative to the challenger. When a corporation challenges an agency decision that regulates water pollution or finds an unfair labor practice, the agency appears liberal relative to the challenger. This coding scheme does introduce some imprecision, which we attempted to correct by investigating individual cases; but as compared to the alternative of ad hoc evaluation of each agency policy, its objectivity and its easy administrability are its virtues. It is important not to be confused by the measure: A Republican administration might issue many decisions that are relevantly liberal, in the sense that companies find it worthwhile to challenge them, and observers might nonetheless conclude that those decisions are conservative by some objective measure.

Our second proxy for the political direction of the agency decision is whether the case was decided during a Democratic or Republican administration. As a general rule,

\footnotetext{
${ }^{77}$ Lee Epstein and Gary King, Empirical Research and the Goals of Legal Scholarship: The Rules of Inference, 60 U. CHI. L. REv. 1 (2002). See also Joshua Fischman, Collegiality in the Courts of Appeals: An Empirical Analysis, MIT Department of Economics Working Paper (January 16, 2006) (positing structural model that allows for unobserved heterogeneity within parties of the appointing president).

${ }^{78}$ Keith T. Poole and Howard Rosenthal, Congress: A POLITICAL-ECONOMIC History OF Roll CALL Voting (1997); Nolan M. McCarthy and Keith T. Poole, Veto Power and Legislation: An Empirical Analysis of Executive and Legislative Bargaining from 1961 to 1986, 11 J. L. ECON. \& ORG. 282 (1995); Gregory C. Sisk and Michael Heise, Judges and Ideology: Public and Academic Debates about Statistical Measures, 99 Nw. U. L. REV. 743 (2005).

${ }^{79}$ Daniel R. Pinello, Linking Party to Judicial Ideology in American Courts: A Meta-Analysis, 20 JusT. SYS. J. 219 (1999).
} 
the positions of agencies under Democratic presidencies are certainly more liberal (or less conservative) than those of agencies under Republican presidencies. To the extent that this generalization is crude, it remains independently important to understand how judicial behavior changes across administrations. A potential difficulty with this measure is that litigation may take years to resolve, and courts of appeals might well be asked to evaluate a regulation, initially issued under the Clinton Administration, during the Bush Administration. When litigation extends across administrations of opposing parties, misattributions may occur. But it is not entirely clear that the relevant question is the political affiliation of the administration that initially issued a regulation or a final order; perhaps what matters is the affiliation of the administration that is litigating the case. Note that a new administration has the opportunity to reverse agency positions and settle ongoing cases before the court issues its decision. ${ }^{80}$ In any event, our findings are not significantly affected if we adjust the data to consider the administration that originally issued the regulation or order.

\section{B. Judicial Votes and Partisan Affiliations}

1. Validation rates. Table 1 reports the rates at which circuit judges vote to validate the decisions of the EPA and NLRB under the arbitrary and capricious and substantial evidence standards. ${ }^{81}$ Column (1) shows total validation rates for Democratic and Republican appointees. It reveals that overall, Democratic appointees vote with significantly higher frequency to validate decisions of the EPA and NLRB. The overall validation rate under arbitrariness review is quite close to the average validation rate under Chevron of $64 \%{ }^{82}$ But a difference between arbitrariness review and Chevron is immediately apparent. In the Chevron cases, the overall validation rates of Democratic and Republican appointees are the same, while under arbitrariness review the validation

\footnotetext{
${ }^{80}$ For clarity, we refer to the administrations as Republican or Democratic, but over the time period studied, 1996-2006, the Clinton Administration was the only Democratic administration, and the administration of George W. Bush was the only Republican administration.

${ }^{81}$ It is generally believed that EPA decisions are typically reviewed under the arbitrary and capricious standard, and NLRB decisions under the substantial evidence standard, but the belief is too crude. Some NLRB decisions are set aside as arbitrary, and some EPA decisions are evaluated, under relevant statutes, for lack of substantial evidence.

${ }^{82}$ Miles and Sunstein, supra note, at 849.
} 
rate of Democratic appointees is nine percentage points higher than that of Republican appointees.

What accounts for this difference? The answer lies in the higher proportion of liberal agency decisions among the arbitrariness cases, which makes ideological differences immediately detectable. Decisions by the NLRB comprise a far larger share of our data set here, and a larger share of these decisions are liberal by our standards. (Recall that those standards are relative, not absolute; an employer might challenge an NLRB decision that has a Republican majority, even though the decision is far more conservative than what would emerge from an NLRB with a Democratic majority.) NLRB decisions account for $92 \%$ of the arbitrariness cases but only $25 \%$ of the Chevron cases. In addition, over 94\% of the NRLB decisions reviewed for arbitrariness were liberal, ${ }^{83}$ while $67 \%$ of those reviewed under Chevron were coded as liberal. In contrast, EPA decisions, both under Chevron and arbitrariness review, were roughly evenly split between liberal and conservative decisions. Because a disproportionate share of the agency decisions subjected to arbitrariness review were liberal, ideological differences are immediately apparent in arbitrariness data.

Although we do not have a definitive explanation for the differences in the number and nature of the two agencies' decisions, we believe that the underlying reason is straightforward. ${ }^{84}$ The EPA makes essentially all of its policies via rulemaking, and the number of rules in any particular year is relatively small. Because they are conducted against the background of clear regulations, EPA adjudications frequently involve the application of settled law to not-much-disputed fact, and the room for challenge in court

\footnotetext{
${ }^{83}$ This figure is consistent with prior studies of NLRB decisionmaking. See William N. Cooke, et al, The Determinants of NLRB Decision-Making Revisited, 48 Indust Lab Rel Rev 237, 239 (1995) (showing that $88 \%$ of unfair labor practice charges reaching the level of circuit court decisions were against employers).

${ }^{84}$ Researchers have long observed wide differences across agencies in the rate at which the Supreme Court validates their decisions. Bradley C. Cannon and Michael Giles, Recurring Litigants: Federal Agencies before the Supreme Court, 25 Western Pol Q 183 (1972) (reporting that agency success rates before the court range from 56\% to 91\%); Roger Handberg, The Supreme Court and Administrative Agencies, 19651978, 6 J Contemp L 161 (1979) (reporting agency success rates before the Supreme Court ranging from 58\% to 91\%); Donald W. Crowley, Judicial Review of Administrative Agencies: Does the Type of Agency Matter?, 31 Western Pol Q 265 (1987) (finding that when agencies are classified as economic have an 80\% success rate before the Court while those classified as social have a $68 \%$ success rate); Ronald S. Sheehan, Administrative Agencies and the Court: A Reexamination of the Impact of Agency Type on Decisional Outcome, 43 Western Pol Q 875 (1990) (reporting that social and economic agencies have similar success rates overall but that substantial variation exists when social agencies' decisions are classified as liberal or conservative).
} 
is not large. By contrast, the NLRB makes essentially all of its policies via adjudication, and the number of adjudications in any particular year is large. Moreover, there is considerable room for challenging the NLRB's judgments about policy and fact. The making of national labor policy through case-by-case decisionmaking has attracted considerable skeptical attention in the Supreme Court itself. ${ }^{85}$ The large number of NLRB cases in our sample reflects the fact that the NLRB makes many more decisions that are subject to a plausible challenge on arbitrariness or substantial evidence grounds. By contrast, a high percentage of EPA decisions can be challenged on Chevron grounds, and a high percentage of NLRB decisions cannot be; hence the proportions in Chevron cases are less lopsided.

This sizable gap in the ideological direction of the agency decisions generates a difference in the validation rates across the two agencies. Figure 1 shows the rates at which judges of both parties voted to validate the decisions of the two agencies. The EPA enjoyed a higher rate of validation when its decisions faced challenges for arbitrariness. Overall, judges voted to validate EPA decisions $72 \%$ of the time compared to only $62 \%$ for the NLRB. ${ }^{86}$ The EPA's decisions also produced a more modest (but still significant) partisan gap in the judges' voting. The rate at which Democratic and Republican appointees voted to reject arbitrariness challenges to EPA decisions differed by fewer than five percentage points. The gap for NLRB decisions was more than twice as large. Democratic appointees voted to validate NLRB decisions $69 \%$ of the time while Republican appointees did so only $58 \%$ of the time.

The differences across agencies have many similarities as well as some contrasts with our earlier findings with respect to Chevron review. ${ }^{87}$ The primary contrast is that under Chevron, the NLRB enjoyed a slightly higher validation rate than the EPA, while under arbitrariness review, this ordering is reversed. The primary common feature is that under both arbitrariness review and Chevron, the partisan gap in validation rates is largest for NLRB decisions. Evidently the labor-management relations that come to the federal

\footnotetext{
${ }^{85}$ See Allentown Mack, supra note.

${ }^{86}$ Despite the difference across these two agencies, these validation rates are similar to those prior researchers have found in appellate court review of administrative agency decisions. See David $\mathrm{H}$. Willison, Judicial Review of Administrative Decisions: Agency Cases before the Court of Appeals for the District of Columbia, 1981-84, 14 Am Pol Rev 371 (1986); Martha Anne Humphries and David R. Songer, Law and Politics in the Judicial Oversight of Federal Administrative Agencies, 6 J Pol 207 (1999).

${ }^{87}$ Miles and Sunstein, supra note, at 852-54.
} 
courts of appeals are more ideologically contentious than are the environmental issues, which might well appear more technical. Perhaps, too, courts are more reluctant to invalidate rules than to invalidate the outcomes of particular adjudications.

When we decompose the data by examining the ideological content of the agency decision, we find even more substantial differences in the behavior of the two groups of appointees.

2. Political voting and failed aspirations. Columns (2) and (3) of Table 1 stratify the voting rates by the partisan policy direction of the agency decision, and we now see an especially sharp contrast in the voting patterns of Republican and Democratic appointees. We are able to demonstrate for the first time ${ }^{88}$ that judicial policy judgments play an unquestionable role under arbitrariness review.

(a) Liberal agencies, conservative agencies. When the agency decision is conservative, Democratic appointees vote to conclude that the agency was arbitrary and capricious at a rate that is 16 percentage points lower than when the agency decision is liberal. The pattern is in the opposite direction for Republican appointees. When the agency decision is liberal, Republican appointees vote to validate at a rate that is 14 percentage points lower than when it is conservative. These patterns imply that the validation rates of Democratic appointees are nearly 13 percentage points above that of their Republican counterparts for liberal agency decisions and almost 17 percentage points below that of the Republicans for conservative agency decisions- to say the least, a dramatic difference in the operation of hard-look review.

These findings contain striking similarities to our previous analysis of judicial review under Chevron. The frequency of agency validation is nearly identical under the arbitrary and capricious review as it is under Chevron; both are about $64 \%{ }^{89}$ This finding bears on the concern Justice Breyer voiced two decades ago, to the effect that under existing doctrine, agencies might be significantly more likely to lose on issues of fact and policies than on issues of law. ${ }^{90}$ Our data do not confirm this prediction. Rather, the data appear consistent with now-standard analyses of litigant decisionmaking. Recall that

\footnotetext{
${ }^{88}$ A more limited data set, focusing on EPA decisions in the DC Circuit, finds a similar conclusion. See Revesz, supra note.

${ }^{89}$ Miles and Sunstein, supra note, at 849-50.

${ }^{90}$ See Breyer, supra note.
} 
litigants should be expected to adjust their behavior to the prevailing standard of review, ${ }^{91}$ and the roughly similar validation rates under arbitrariness review and Chevron suggest that litigants readily make these adjustments. Because litigants are likely to adjust their decision in accordance with the intensity of review, our figures cannot be taken to answer the question whether Chevron review is more rigorous that arbitrariness review, or vice-versa. A constant rate of $64 \%$ is possible even if one standard is far more searching than another, if we assume, as seems likely, that the selection of cases will be affected by litigant perceptions of when they are least likely to lose.

Both Chevron and State Farm seek to cabin the influence of judicial ideology in the review of agency decision making. An evident aspiration of the Chevron approach is to limit the role of judicial judgments in the domain of policy. ${ }^{92}$ Despite its command of deference to reasonable agency interpretations of law, the persistence of judicial politics under Chevron is plain. ${ }^{93}$ State Farm does call for judicial scrutiny of agency judgments about fact and policy, but the Court made clear that so long as the agency offered "a reasoned analysis," it would be permitted to do as it saw fit. ${ }^{94}$ Indeed, State Farm must be taken in the context of both Overton Park, where the Court emphasized that "the ultimate standard of review is a narrow one" affording the agency "a presumption of regularity,"95 and Vermont Yankee, where the Court stressed that the ultimate decision is for agencies, not for courts. ${ }^{96}$ The Court has yet to offer an unambiguous warning about the politicization of judicial review under scrutiny of possible "arbitrariness," but the key decisions are plainly meant to reduce the relevant risks.

Notwithstanding the Court's aspirations, the figures in Table 1 show a large role for judicial policy preferences in arbitrariness review. The magnitude of the fluctuation in validation rates between liberal and conservative agency decisions is roughly the same in arbitrariness review cases as it is in Chevron cases. Under both standards, the validation rates of Democratic and Republican appointees see-saw in response to the ideological content of the agency decision. When the agency decision is liberal, Democratic

\footnotetext{
${ }^{91}$ George L. Priest and Benjamin Klein, The Selection of Disputes for Litigation, 13 J Leg Stud 1 (1984). See also the discussion in Section VI, infra.

${ }^{92}$ See Elliott, supra note.

${ }^{93}$ See Miles and Sunstein, supra note, at 860.

${ }^{94} 463$ US at 49.

${ }^{95}$ Citizens to Preserve Overton Park v. Volpe, 401 US 402 (1971).

${ }^{96}$ Vermont Yankee Nuclear Power Corp. v NRDC, 435 US 519, XXX (1978).
} 
appointees validate more often by about 14 percentage points, and when the agency decision is conservative, Republican appointees validate more often by about 17 percentage points. The results demonstrate that arbitrariness review under the State Farm framework has failed to eliminate the influence of judicial ideology in review of agency decisions of policy and fact. ${ }^{97}$

(b) Republican administrations, Democratic administrations. Table 2 presents validation rates for the two groups of judges when the party of the current president is used as the measure of the political valence of the agency decision. We anticipated that Republican appointees would be more likely to uphold decisions under Republican administrations and that Democratic appointees would be more likely to uphold decisions under Democratic administrations - and indeed this is the pattern we observe in the Chevron context. ${ }^{98}$ We were initially surprised to find that the validation rates do not correlate strongly with the party of the current president. During a Democratic administration, Democratic appointees vote to validate EPA and NLRB decisions $68 \%$ of the time, a rate two percentage points lower than their validation rate during Republican administrations. Directly contrary to what one might anticipate, the validation rates of Republican appointees are actually about 7 percentage points higher during Democratic administrations, though this difference is not statistically significant.

These patterns show that when reviewing EPA and NLRB decisions for arbitrariness, the validation rates of Democratic appointees are higher than those of Republican appointees, irrespective of which party currently holds the presidency. During Democratic presidencies, the validation rates of Democratic appointees in these cases were 12 percentage points higher than that of Republican appointees, and during Republican presidencies, this difference was only 6.5 percentage points. But the gap between these figures (12 versus 6.5 ) is not statistically meaningful. What is clear is that Democratic appointees validate EPA and NLRB decisions at higher rates during both the Democratic and Republican administrations during this period.

\footnotetext{
${ }^{97}$ When we decompose these data by individual agency, the patterns are similar. The see-saw pattern is very sharp in the NLRB decisions. It is more muted in the EPA decisions. There, the validation rates of Republican appointees respond little to the ideological direction of the agency decision while the validation rates of Democratic appointees fluctuates by about 20 percentage points.

${ }^{98}$ See Miles and Sunstein, supra note.
} 
At first blush, Tables 1 and 2 present a confusing and inconsistent picture of whether judges are responsive to the ideological content of the agency decision. In Table 1 , the validation rates of appointees from both parties appear highly responsive to political considerations, while in Table 2 the validation rates of Democratic appointees appear consistently higher than those of Republican appointees. How can these patterns be explained?

The answer lies in the fact that Republican administrations often produce a rule, decision, or order that is relevantly liberal, in the sense that it is challenged by a company that is regulated by an EPA rule or displeased by a finding of an unfair labor practice by the NLRB. So too, a Democratic administration may and often does produce a decision or rule that is relevantly conservative, in the sense that it is challenged by a public interest group or a labor union. It is for this reason that in these data the purely political coding of the agency's decision is a more accurate measure than the party of the administration at the time the court issues its ruling. As previously described, the arbitrariness cases in the data are disproportionately liberal decisions by the NRLB. ${ }^{99}$

For that reason, it should not be puzzling that in Table 2, the validation rates of Democratic appointees appear higher than those of Republican appointees in both Republican and Democratic administrations. What matters is whether the agency's decision was liberal, not whether it was issued under a Republican president. It follows that if the goal is to assess the role of judicial ideology in arbitrariness review, there is reason for much greater confidence in the estimates based on our direct coding of the agency decisions.

With these qualifications in mind, the central findings are clear. In cases applying arbitrariness review, the validation rates of Democratic appointees exceed those of Republican appointees by at least 6 percentage points. When individual agency decisions are classified according to their ideological content, the role of politics is unmistakable: Democratic appointees are far more likely to uphold liberal decisions than conservative

\footnotetext{
${ }^{99}$ A comparison of the number of conservative agency decisions in Table 1 with the number of decisions arising during Republican administrations in Table 2 makes this point clear. The total number of judges votes in conservative agency decisions, $219(=108+111)$, is far less than the total number of judge votes during Republican administrations, $915(=406+509)$. These totals imply that under the Republican administration during our observation period, most EPA and NLRB decisions reviewed for arbitrariness by Republican appointees were "liberal" in our sense, and this finding explains the apparent anomalies in the voting patterns of those appointees.
} 
ones, and Republican appointees show the opposite pattern. Arbitrariness review is being applied in a way that shows a large influence from judicial policy preferences.

\section{Panel Effects}

1. The standard patterns. A great deal of evidence shows that the composition of appellate panels significantly influences the voting behavior of individual judges. In many domains, the standard pattern includes ideological dampening and ideological amplification. $^{100}$ Dampening occurs when Democratic appointees show unusually conservative voting patterns when sitting with two Republican appointees, and when Republican appointees show unusually liberal voting patterns when sitting with two Democratic appointees. Amplification occurs when the most liberal voting patterns, by individual judges, are found for Democratic appointees on panels consisting of only Democratic appointees, and when the most conservative patterns, by individual judges, are found for Republican appointees on all-Republican panels. ${ }^{101}$

2. The standard patterns here. Democratic appointees typically show increasingly liberal voting patterns as the number of Democratic appointees increases, and Republican appointees typically show increasingly conservative voting patterns as the number of Republican appointees increases. ${ }^{102}$ As we shall soon see, our most striking finding here is a form of ideological amplification, clearly demonstrated once agency and judicial decisions are coded in political terms. In arbitrariness cases, Democratic appointees show heightened liberal voting on DDD panels, just as Republican appointees show heightened conservative voting on RRR panels.

Figure 2 examines whether panel effects are present in the context of validation rates. The rates of Democratic appointees appear in the darkly shaded bars, and those of Republican appointees appear in lightly shaded bars. Notably, the figure shows that overall the validation rates of Democratic appointees are unresponsive to the partisan composition of a panel. When sitting with two other Democrats, the average Democratic appointee votes to validate $72 \%$ of the time. This rate falls by only two percentage points

\footnotetext{
${ }^{100}$ See Sunstein et al., supra note, at 8-9.

${ }^{101}$ See, e.g., Miles and Sunstein, supra note, at 864.

102 See, e.g., id. at 860; Sunstein et al., supra note, at 20-23.
} 
when the panel has one Republican and by only three percentage points when it has two Republican appointees.

In contrast, Republican appointees demonstrate some responsiveness to panel composition. True, the validation rate of the average Republican appointee falls by only three percentage points when she sits with one Democratic appointee and one Republican appointee, rather than two Democratic appointees. But when a panel consists of two other Republicans rather than a Democrat and another Republican, her average validation rate falls by six percentage points. This is a modest but unmistakable form of ideological amplification. $^{103}$

As Table 1 revealed, overall validation rates obscure pronounced ideological patterns. Table 3 therefore decomposes the validation rates of Democratic and Republican appointees by both panel composition and the ideological content of the agency decision. ${ }^{104}$ It compares the validation rates for judges of each party according to whether the panel was politically "mixed" and whether the agency decision was liberal. Column (1) of Table 3 shows the overall validation rates, and these figures are comparable to those in Figure 2. But this grouping of the data emphasizes that validation rates in these arbitrariness review cases steadily decline as the number of Republican appointees on a panel grow, and that the validation rates of Democratic and Republican appointees sitting on politically mixed panels are fairly close; they differ by only 6.5 percentage points.

The remaining columns of Table 3 display the relationship of validation rates to the nature of the agency decisions. Two patterns are immediately evident. First, politically unanimous panels exhibit strong ideological responses to the content of the agency decisions. The average validation rate of a panel consisting of three Democratic appointees is 23 percentage points higher when the agency decision is liberal rather than conservative! For panels consisting of three Republicans, the response is even stronger

\footnotetext{
${ }^{103}$ This movement in the validation rates of Republican appointees implies a large difference in the validation rates of politically uniform panels. Even before considering the political direction of the agency decisions, the difference in the validation rates of all-Democratic and all-Republican panels is 17 percentage points. Again, this difference is due primarily to the drop in the validation rates of allRepublican panels.

${ }^{104}$ Because ideological content matters, and the political affiliation of the president does not, we do not separately report panel effects according to that affiliation. We have analyzed the relevant data, however, and our findings are available on request.
} 
but in the opposite direction. The average validation rate of all-Republican panels in these arbitrariness review cases is 28 percentage points lower when the agency decision is liberal rather than conservative.

These patterns imply that when the agency decision is liberal, the validation rate of a Democratic appointee sitting on a panel with two other Democrats is 23 percentage points higher than that of a Republican sitting with two other Republicans. When the agency decision is instead conservative, the direction of this gap reverses but its magnitude remains very large. The validation rate of a Democratic appointee sitting with two other Democratic appointees is 28 percentage points below that of a Republican appointee sitting with two other Republican appointees. Here, then, is a clear "smoking gun” with respect to panel effects.

These figures reveal that the see-sawing of the validation rates of Democratic and Republican appointees in response to the nature of agency decisions shown in Table 1 is attributable to a large degree to the behavior of judges on politically uniform panels. A comparison of rows (A) and (D) in Table 4 shows a pattern of see-sawing validation rates akin to that in Table 1 - only more pronounced. The validation rates of Democratic appointees sitting with two other Democrats are almost the mirror image of those of Republican appointees sitting with two other Republicans.

For judges sitting on politically mixed panels, the movement of validation rates in response to the ideological content of the agency decision is muted but not entirely absent. A Democratic appointee on a politically mixed panel has an average validation rate 13 percentage points higher when the agency decision is liberal rather than conservative, and this movement is statistically significant. A Republican appointee on a politically mixed panel votes to validate under arbitrariness review 8 percentage points less often when the agency decision is liberal rather than conservative, but this difference is not statistically significant.

These patterns also mean that when the agency decision is liberal, Democratic appointees on politically mixed panels vote to validate about 9 percentage points more often than Republican appointees on politically mixed panels. The opposite happens when the agency decision is conservative; the average Democratic appointee on a politically mixed panel votes in favor of validation 12 percentage points less often than 
the average Republican appointee on a politically mixed panel. Even on politically mixed panels, Democratic and Republican appointees react to the ideological content of agency decisions in the predicted directions, and their responses are large enough to generate a see-saw pattern in validation rates, albeit a pattern less pronounced than on politically uniform panels.

3. Comparing Chevron. As striking as these ideological patterns are, the role of judicial partisanship under Chevron was just as distinct, if not more so. ${ }^{105}$ In terms of raw numbers, the effect is even more dramatic. The rate at which Democratic appointees sitting with two other Democrats voted to validate liberal agency interpretations of statutes was 32 percentage points higher than their validation rate for conservative agency interpretations. For Republican appointees sitting with two other Republican appointees, the validation rate was more than $40 \%$ higher when the agency interpretation was conservative rather than liberal. Hence it is plausible but false to speculate that Chevron has imposed a greater discipline on political voting than can be found in the domain or arbitrariness review. In our data, at least, the speculation is rejected.

When politically mixed panels reviewed agency interpretations under Chevron, the movement in validation rates of Republican appointees was not statistically significant, while for Democratic appointees, it was an increase of 20 percentage points, which was statistically significant. Interestingly, in arbitrariness review cases, Democratic appointees on mixed panels also show a statistically significant response to the nature of the agency decision while Republican appointees on mixed panels do not. More importantly, the sample sizes preclude any strong inferences about whether the response of politically unanimous panels to the nature of the agency decisions is larger under Chevron than under arbitrariness review. Nevertheless, the results in Table 3 indicate that when the ideological content of the agency decision is considered, the partisan composition of panels exerts a substantial influence on judges' exercise of arbitrariness review.

4. Conclusions. The discussion of panel effects has been regrettably complex, but the major conclusions are plain. In arbitrariness review cases, judicial votes are significantly affected by the composition of the panel. The political party of the

\footnotetext{
${ }^{105}$ Miles and Sunstein, supra note, at 855-58.
} 
appointing president is a good predictor of judicial behavior in such cases, and the political party of the president who appointed the other two judges on the panel is also a strong predictor. A key finding is that the more Democratic appointees on a panel, the greater the likelihood of validation. But perhaps our most striking finding here involves the reaction of judges on politically uniform panels to the nature of the agency decisions. The willingness of these judges to validate an agency's decision under the arbitrariness standard correlates strongly with the ideological direction of the agency decision. On $R R R$ and DDD panels, judges are at least 20 percentage points more likely to reject an arbitrariness challenge when the agency decision agrees with their presumed ideological preference than when it disagrees. This finding suggests that the influences of judicial ideology and panel composition exert approximately the same power in arbitrariness review as they do in review under Chevron.

\section{Liberal Voting, Conservative Voting}

1. Liberal voting rates. Another way to analyze the votes of the judges to examine whether their votes can be considered "liberal." We classified a judge's vote as liberal if it was a vote either to validate a liberal agency decision or to invalidate a conservative agency decision. Table 4 presents comparisons of the liberal voting rates of Democratic and Republican appointees. Column (1) of Table 4 shows the overall liberal voting rates of Democratic and Republican appointees, and consistent with conventional wisdom, Democratic appointees cast liberal votes far more frequently. Democratic appointees vote in a liberal way $68 \%$ of the time, which is about 12 percentage points higher than the percentage for Republican appointees. It is worth underlining here that we are concerned with judicial decisions striking down agency judgments of fact or policy as arbitrary or unreasonable, where the convictions of federal judges are not supposed to play a role; but in that domain, a 12 percentage point difference shows a significant effect from judicial preferences.

This pattern is comparable to the liberal voting rates that prevail in cases reviewing EPA and NLRB decisions under Chevron. When the statutory interpretations of these agencies faced challenges, Democratic appointees voted in a liberal way $67 \%$ of the time, and Republican appointees $50 \%$ of the time. The slightly lower rate of liberal 
voting by Republican appointees in Chevron cases is not statistically distinguishable from their rate of liberal voting in arbitrariness cases. The partisan gap in liberal voting in cases reviewing the agency decisions for arbitrariness is effectively identical to gap present in cases applying the two steps of Chevron.

The next two columns of Table 4 break out the liberal voting rates according to the party of the current president. As seen previously, the party of the current president is an imprecise measure of the ideological content of the agency decisions in these arbitrariness cases. The final column of Table 4 shows that the liberal voting rates of both Democratic and Republican appointees rise by about 6 percentage points when the party of the current president changes. For Democratic appointees, the direction of this movement is contrary to the standard prediction, which is that a judge votes more consistently with her presumed ideology when the current president belongs to her own political party. The finding that Democratic appointees vote in a liberal fashion during the Republican presidency is consistent with our earlier claim that many of the NLRB decisions during our observation period are relevantly liberal.

2. Panel effects. Figure 3 presents liberal voting rates of the circuit judges by their political party and by the partisan composition of the panel. The liberal voting rates of Republican appointees are everywhere below those of Democratic appointees, but they are highest when the panel has a DDR configuration. In that setting, Republican appointees cast liberal votes $64 \%$ of the time, which is 8 percentage points higher than when the panel has two Republicans and one Democrat. Moreover, Republican appointees cast liberal votes most infrequently when the panel consists of three Republicans. Both ideological dampening and amplification thus characterize the liberal voting rates of Republican appointees.

In contrast, Democratic appointees show much less fluctuation in their liberal voting rates. When a panel consists of three Democrat appointees, they cast liberal votes $71 \%$ of the time, a rate that is only two percentage points higher than when the panel has two Democrats and one Republican. Their liberal voting rates slip to $64 \%$ when the Democratic appointee sits with two Republicans. For these Democratic appointees, ideological dampening is a feature of their liberal voting in arbitrariness cases while 
ideological amplification is not. ${ }^{106}$ A consequence of these patterns is that the liberal voting rates of Republican appointees fluctuate with the composition of the panel about twice as much as those of Democratic appointees (i.e., a movement of 15 percentage points for Republicans versus 7 for Democrats).

These results are generally consistent with our findings for Chevron, but some subtle differences are also present. ${ }^{107}$ Under both standards of review, Democratic appointees cast liberal votes more often than Republicans irrespective of the panel composition, and the liberal voting rates of judges of both parties fluctuated to some degree with panel composition. But in the Chevron cases, the liberal voting rates of Democratic appointees, rather than Republicans, appear more responsive to panel composition. The liberal voting rates of Democratic appointees in Chevron cases climb steadily as the number of Democrats on a panel grew. The liberal voting rates of Republican appointees under Chevron were steady as long as Republicans formed a majority of judges on the panel, and they dipped when a Republican sat with two Democrats. While these patterns invite interpretations about the differences between the two standards of review, the noisiness of estimates prevents us from drawing strong inferences.

\section{The Distinctiveness of the Court of Appeals for the District of Columbia}

In view of its importance and its specialized docket, which consists in large part of regulatory problems, the Court of Appeals for the District of Columbia is the appellate court most frequently studied by administrative law scholars and political scientists. ${ }^{108}$ Precisely because of its distinctive role, a natural question is whether the voting behavior of D.C. Circuit judges is representative. To what degree does the unique nature of the D.C. Circuit lead it to perform in distinctive ways? This section provides some answers.

\footnotetext{
${ }^{106}$ We do not have an explanation for this intriguing finding. Generally, ideological amplification and ideological dampening move hand-in-hand. In some cases, neither is present, apparently because judges have strong convictions and are not much influenced by the views of their colleagues; the cases of abortion and capital punishment are the key examples here. See Sunstein et al., supra note. Why dampening would occur, but amplification would not, is not simple to explain. Perhaps Democratic appointees, in the relevant cases, are willing to offer collegial concurrences (hence dampening) but vote their convictions so long as they are in the majority (hence Democratic appointees show the same patterns on DDR and DDD panels).

${ }_{107}$ Miles and Sunstein, supra note, at 860-61.

${ }^{108}$ See, e.g., Revesz, supra note.
} 
Our most important findings are that the validation rate on the D.C. Circuit is significantly lower than the validation rate elsewhere, and that the court as a whole shows conservative voting patterns-so much so that Democratic appointees, on the D.C. Circuit, show voting patterns akin to that of Republican appointees elsewhere.

\section{A. Three Initial Findings}

Table 5 reports the rates at which Democratic and Republican appointees to the D.C. and other circuits vote to validate decisions of the EPA and NLRB. Three aspects of these validation rates are immediately apparent. First, despite its specialized docket, the D.C. Circuit accounts for only 187 of the 653 cases, or somewhat less than a third of the total. This is a significantly lower share than in judicial applications of Chevron. Of the 227 challenges to the EPA and NLRB under Chevron over the same time period, the D.C. Circuit decided 109 of them, or $48 \%$.

Second, the final row of Table 5 shows that in both the D.C. Circuit and other circuits, the overall validation rates of Democratic appointees are higher than those of Republican appointees. In the D.C. Circuit, Democratic appointees vote to validate at a rate about 8 percentage points higher than their Republican colleagues, while in other circuits, they do so at a rate about 11 percentage points higher. The pervasiveness of this partisan gap is meaningful, but the inter-circuit difference of 3 percentage points (i.e., 8 versus 11) is not. Democratic appointees both within and outside of the D.C. Circuit voted to validate agency decisions significantly more often than Republican appointees.

The third finding is the most interesting. The final column of Table 5 shows that both Democratic and Republican appointees to the D.C. Circuit are much less willing to validate the decisions of the EPA and NLRB in arbitrariness cases than are judges in other circuits. The Democratic appointees to the D.C. Circuit were 7 percentage points less likely to validate than their counterparts in other circuits, while for Republicans the difference was slightly larger, 10 percentage points. This contrast is striking both for its size and for its consistency across partisan affiliations. 


\section{B. Of Familiarity and Contempt}

A promising explanation of these differences is the greater experience of D.C. Circuit judges in reviewing administrative agencies. With the exception of a very few judges whose tenure on the bench only briefly overlapped with our sample period, every D.C. Circuit judge in this period appears at least two dozen times in our data. ${ }^{109}$ The median number of votes in our data from such D.C. Circuit judges is 53 and the mean is 52.2. Outside of the D.C. Circuit, judges hear arbitrariness challenges to EPA and NLRB decisions far less frequently. The median number of judges deciding cases involving the EPA and NLRB is two and the mean is $4.1 .^{110}$ If we were to calculate the median number of relevant EPA and NLRB cases heard by the typical appellate judge outside the D.C. Circuit, it would likely be zero, because many judges never sit on cases requiring arbitrariness review and thus never appear in our data.

Judges who are experienced in conducting arbitrariness review might well become harder reviewers. With greater experience, judges may grow more confident in their own judgments about what is arbitrary and thus may be more willing to invalidate agency decisions. In addition to having greater experience with hard look review generally, judges may be more willing to invalidate if they have previously reviewed the decisions of a specific agency. Familiarity may not necessarily breed contempt, but repeated play may allow judges to learn where particular agencies are prone to weaknesses in their procedures or their analyses. It is reasonable to speculate that the higher invalidation rates in the D.C. Circuit, for both Democratic and Republican appointees, is at least partly explained in these terms.

\footnotetext{
109 Judges who left the D.C. Circuit relatively early in our observation period are Judges James Buckley, Ruth Bader Ginsburg, and Patricia Wald, and those who joined it relatively late are Judges Janice Rogers Brown and Thomas Griffith. Then-Judge John Roberts is both a late arrival and an early departure in our data. The mean number of votes from each of these judges is 8.1 and the median is 6 .

${ }^{110}$ Another example of this difference is the gap between the judges in our sample who have decided the most hard look reviews of the EPA and NLRB. The D.C. Circuit judge in our data who voted in the most arbitrariness review cases, Judge Karen LeCraft Henderson, heard 66 of them. Outside of the D.C. Circuit, the judge in our data who sat on the most hard look cases, Judge Joel Flaum in the $7^{\text {th }}$ Circuit, heard 25 of them. Close behind Judge Flaum are his $7^{\text {th }}$ Circuit colleagues Judges Diane Wood and Ilana Rovner, each with 24 decisions in these cases.
} 


\section{Disaggregations}

1. Validation rates. Table 6 breaks out the comparison of the D.C. Circuit and other circuits by the ideological content of the agency decision. The patterns are consistent with the previous tables. Most notably, the circuit groupings feature the standard see-saw pattern in which the validation rates of Democratic appointees are higher than those of Republican appointees when the agency decision is liberal-and when the agency decision is conservative, the opposite pattern can be found. But this pattern emerges most strongly outside of the D.C. Circuit.

For D.C. Circuit judges, the validation rates of Republican appointees appear more responsive to the ideological content of the agency decision than those of their Democratic colleagues. Panel A shows that when the agency decision is liberal rather than conservative, the validation rates of Democratic appointees are merely 6 percentage points higher. For Republican appointees on the D.C. Circuit, this difference is much larger-nearly 20 percentage points! —and the movement in validation rates for these Republican appointees is statistically significant. On the D.C. Circuit, Republican appointees appear to show far more ideological voting than do Democratic appointees.

For judges on other circuits, the opposite is true. Panel B shows that when the agency decision is liberal, Democratic appointees validate at a very high rate, $76 \%$, and when the agency decision is not liberal, their validation rate falls to 51\%, a drop of 25 percentage points. The nature of the agency decision also has a sizable impact on the validation rates of Republican appointees. Republican appointees on appellate courts other than the D.C. Circuit vote to validate liberal agency decisions under hard look review about $60 \%$ of the time and conservative decisions about $72 \%$ of the time. The difference for Republican appointees outside the D.C. Circuit of 12 percentage points is about half as large as the 25-point difference for Democratic appointees-but it is still statistically significant.

In sum, the validation rates of Democratic and Republican appointees both inside and outside of the D.C. Circuit appear to respond to the ideological direction of the agency decisions. These responses produce the now-familiar see-sawing of validation rates. Democratic appointees validate at higher rates than Republicans when the agency is liberal, and vice-versa when the agency decision is conservative. A general conclusion is 
that the influence of judges' political commitments on arbitrariness review is not limited to any particular circuit court.

2. Liberal and Conservative Voting. A possible explanation for the lower validation rates of D.C. Circuit judges is that they are simply more conservative than their colleagues on other circuits. The relative lack of responsiveness of Democrats on the D.C. Circuit to the ideological content of the agency decision-as shown in Table 5also suggests that Democratic appointees to that court may be more conservative than Democratic appointees on other courts of appeals.

To test this hypothesis, Tables 7 presents comparisons for liberal voting rates. The table reveals that in addition to having higher invalidation rates, D.C. Circuit judges—of both parties-are significantly more conservative than judges of other circuits in their voting patterns in arbitrariness cases. Republican appointees to the D.C. Circuit cast liberal votes less often than their counterparts in other circuits by about 8 percentage points. The difference for Democratic appointees is almost double that; the average Democratic appointee to the D.C. Circuit casts liberal votes in these arbitrariness review cases about $14 \%$ less often than Democrats in other circuits.

Yet the lower liberal voting rates of D.C. Circuit judges does not imply that Democrats and Republicans on the D.C. Circuit are equally conservative. In both the D.C. Circuit and other circuits, Democratic appointees vote in the liberal manner more often than Republican appointees. This partisan gap about 9 percentage points in the D.C. Circuit and 15 percentage points in other circuits, but the six-point difference between these two figures is not statistically significant. We cannot conclude that the partisan gap is larger on other circuits, but we readily infer that Democratic appointees on all appellate courts cast liberal votes more often in arbitrariness review of EPA and NLRB decisions than Republican appointees do. We will explore shortly a complexity with drawing some tempting conclusions from this finding; for the moment, let us continue with the numbers.

While a partisan gap remains within each circuit, the lower liberal voting rates of Democratic appointees on the DC Circuit can be further illustrated by comparing them to Republican appointees in other circuits. Put differently, does the average Democratic appointee to the DC Circuit have liberal voting rates as low as the average Republican 
appointee to another circuit court? Table 7 shows, strikingly, that the answer is "yes." D.C. Circuit Democrats cast liberal votes $58 \%$ of the time, while Republicans on other circuits did so $57 \%$ of the time. At least in terms of this set of arbitrariness review opinions, D.C. Circuit Democrats behave like Republicans on other federal appellate courts. A look back at Table 5 reveals that these two groups of judges are also indistinguishable in terms of their validation rates in these cases. D.C. Circuit Democrats voted to validate the agency decisions $62 \%$ of the time, while Republicans on other circuits did so $61 \%$ of the time.

We have referred to a complexity in interpreting these findings, and it is easy to describe: Relevantly different cases might be brought before the DC Circuit than before other courts of appeals. In some cases, the DC Circuit has exclusive jurisdiction to review EPA action, and pragmatic constraints might ensure that "liberal" challenges to agency action are relatively weak and that "conservative" challenges to agency action are relatively strong. In other cases, litigants might decide to bring particular cases in the DC Circuit, or decide not to do so, and these selection effects might defeat easy comparisons. We have therefore spoken of differences in liberal voting rates without drawing strong conclusions about whether DC Circuit judges are more conservative in the abstract. Because of the mix of cases in the DC Circuit is not a random sample, our evidence is merely suggestive.

However this issue is best understood, the central lessons are plain. In cases challenging EPA and NLRB decisions for arbitrariness, judges on the D.C. Circuit invalidate agency decisions more readily than do their counterparts in other circuits. Both Democratic and Republican appointees to the D.C. Circuit show lower liberal voting rates than do their counterparts in other circuits. At the same time, the partisan gap between Democratic and Republican appointees does not lessen: In both the D.C. and other circuits, Democratic appointees cast liberal votes in arbitrariness review cases significantly more often than Republican appointees. In terms of their liberal voting rates in such cases, Democratic appointees to the D.C. Circuit are equivalent to Republican appointees to other circuit courts.

\section{Normative Issues}

We now turn to normative issues. It is tempting to think that an understanding of validation rates and of the role of judicial ideology would bear on and perhaps even resolve the continuing debate over hard look review. And in the end, we conclude that 
our findings can reasonably be taken to suggest the importance of diminishing that role, and also provide significant ammunition for those who believe that such review should be softened. ${ }^{111}$ But this lesson is heavily qualified, and the qualifications may be as important as the ultimate conclusion. The less ambiguous lesson is that it would be highly desirable to reduce the role of judicial policy preferences in conducting arbitrariness review.

\section{A. Problems and Puzzles}

Let us begin with the validation rate. In arbitrariness cases, the validation rate is 64 percent. ${ }^{112}$ Some people might find that rate alarmingly low. After all, agencies are supposed to lose not when they are wrong but when their judgments of policy and fact are "arbitrary" (or lacking substantial evidence). An invalidation rate of 36 percent seems quite high.

To make progress on the normative issues, suppose we found that the validation rate was lower than it actually is-say, 30 percent. Would it be appropriate to conclude that the hard look doctrine was too hard? At first glance, the answer would clearly be affirmative. If courts are striking down agency decisions as arbitrary more than half of the time, there is reason to suspect that something is seriously amiss.

But for two reasons, the suspicion might turn out to be wrong. Perhaps more than half of the agency decisions are, in fact, arbitrary. If so, the invalidation rate is nothing to deplore. But there is a more subtle point. As we have suggested, the rate of challenges to agency action will be affected by whether judicial review is aggressive or weak. If courts are aggressive, we should expect to see more challenges, simply because the likelihood of success is higher. If the rate of challenges varies with the stringency of judicial review, then we might hypothesize that it would hover around a fairly constant level—as a first approximation, 50\% (not so far from the overall rate that we in fact find). In other words, the rate of validations might be impervious to changes in the stringency of review.

To see why this is a plausible hypothesis, imagine that the stringency of judicial review was reduced, in next five years, by about half—so that the validation rate would

\footnotetext{
${ }^{111}$ See, e.g., Pierce, supra note.

${ }^{112}$ We have explored NLRB and EPA cases here, but we have also compiled a different data set involving all decisions citing State Farm, and including all such cases, the validation rate is under $60 \%$.
} 
be $82 \%$, all else equal, in five years. The difficulty is that the mix of cases would be most unlikely to remain constant. If litigants are rational, the likelihood of success will affect their decision whether to litigate, and that likelihood will depend on the aggressiveness of arbitrariness review. In all likelihood, many challenges that would have been brought would no longer be brought, simply because such challenges would be a waste of time and money. Even if the stringency of judicial review were cut in half, the overall validation rate could remain 64\%. On certain assumptions about litigant behavior, less stringent review could even produce a lower validation rate, if, for example, only very strong cases were brought. (Hence the relatively higher validation rate for the EPA than for the NLRB may tell us less than first appears.)

Actually things are more complicated still. Agency decisions should also be affected by the likelihood of judicial invalidation. Consider the extreme case of no review, at all, of agency judgments about policy and fact. Without any such review, some agencies would inevitably make some decisions that they will not now make; the rate of arbitrariness would significantly increase. Of course it is likely that arbitrary decisions are already checked by nonjudicial safeguards of various sorts, ${ }^{113}$ and we could imagine a world in which the level of arbitrariness would be very low even without judicial review. But in our world, it is more than reasonable to think that judicial review operates to discourage some decisions, actually or arguably arbitrary, that would be made in its absence. ${ }^{114}$ If this is true, then it is also more than reasonable to think that aggressive review will discourage more decisions than weak review. And if this is true, then aggressive review will operate as a check on its own use. With such review, the mix of agency decisions will shift in the direction of less arbitrariness, and hence the rate of invalidation might well stay constant.

The analysis is analogous to that of the selection of disputes for litigation. In the standard account, the only disputes that advance to trial are those in which each party is sufficiently optimistic about her chance for success at trial that her estimated return from trial exceeds the difference between trial costs and settlement costs. Less optimistic

\footnotetext{
${ }^{113}$ Consider, for example, the process of internal executive branch review. See Stephen Breyer et al., Administrative Law and Regulatory Policy 102-113 (6 ${ }^{\text {th }}$ ed. 2006).

${ }^{114}$ See William Pederson, Formal Records and Informal Rulemaking, 84 Yale LJ 59 (1975) (contending that aggressive judicial review has helped to discipline arbitrary decisions at EPA).
} 
litigants will choose to settle. ${ }^{115}$ Arbitrariness review differs in many ways from trials, but the relevant insight is that both the rate of challenges to agency decisions and the content of agency decisions will respond to the intensity of judicial review.

We can therefore identify two ways in which changes in the intensity of judicial review will influence the case mix: As review becomes less intense, litigants will challenge fewer decisions, and agencies will be more likely to make decisions that aggressive courts would have struck down as arbitrary. In terms of validation rates, the two effects will cut in different directions. Fewer challenges will mean higher validation rates; agency adaptation, in the form of decisions closer to the line of arbitrariness, will mean higher ones.

To know the ultimate consequences of less intense review, we need to know not only the direction but also the magnitude of these two effects. A reduction in the intensity of review should first tend to raise the validation rate. If neither litigants nor agencies are responsive to the intensity of review, an increase in the validation rate would be the sole consequence of less intense review. But if litigants were highly responsive to intensity shifts and if agencies were not, the content of agency decisions would remain the same while litigants would decline to bring the more marginal challenges. The volume of arbitrariness challenges would decline, and the validation rate could remain fairly constant. Or the validation rate could even fall as litigants found it worthwhile to challenge only agency decisions that were most egregious and thus most likely to be invalidated.

Suppose, however, that litigants were not responsive to intensity shifts and agencies were highly responsive. If so, then agencies might issue more arbitrary decisions without suffering a reduction in the validation rate and without inducing an increased flow of challenges. But if the agency let the quality of its decisions decline too much, the greater arbitrariness of decisions would eventually offset the reduction in the intensity of judicial review. In this instance, the volume of challenges might rise and the validation

\footnotetext{
${ }^{115}$ George L. Priest and Benjamin Klein, The Selection of Disputes for Litigation, 13 J Leg Stud 1 (1984). A strong version of the Priest-Klein hypothesis predicts that under certain circumstances the win rate of plaintiffs at trial approaches $50 \%$. We do not consider the fact the validation rate in our EPA and NLRB cases hovers near $50 \%$ to be evidence for this proposition, because the conditions for the Priest-Klein result are not satisfied in State Farm cases. Most important, the stakes in judicial review of agency decisions however the relevant figures might be defined - are unlikely to be symmetrical between plaintiffs and defendants.
} 
rate fall. If both litigants and agencies are highly responsive to intensity shifts, the impact on the quality of agency decisions, the volume of challenges, and the validation rate is far from clear. Without strong assumptions about whether litigants or agencies are more responsive to the intensity of judicial review, the impact on the validation rate is also hard to foresee. These predictions are captured in the following table: [insert Table 8 about here]

It follows that in the abstract, it is difficult to draw firm conclusions about the stringency of review, and about whether existing practice is too lenient or too stringent, from any particular validation rate. In the future, much progress might be made by examining the rate of challenges to decisions by particular agencies or agencies in general-an eminently feasible enterprise. What percentage of EPA rules are actually challenged? Is the percentage higher now than it was five years ago, or ten years ago, or fifteen years ago? Still more progress might be made by a qualitative assessment of the nature and rationality of agency decisions over time-also feasible even if more difficult.

\section{B. Republican Appointees, Democratic Appointees, and the Smoking Gun}

At this point, the validation rates that we observe might be taken to be insufficiently informative about whether courts are reviewing agency decisions too aggressively. But we are particularly interested in party and panel effects, and we should be able to learn more if we attend to the differences between Republican and Democratic appointees. To focus the analysis, suppose that Republican appointees voted to invalidate liberal agency decisions $90 \%$ of the time and to invalidate conservative agency decisions $10 \%$ of the time-and that Democratic appointees showed the opposite pattern. Or suppose that Republican appointees showed an 80\% validation rate during Republican administrations and a 20\% validation rate during Democratic administrations, and that Democratic appointees showed a similar form of favoritism. At first glance, voting patterns of this kind would suggest a serious problem in the real world of arbitrariness review.

If these were the observed patterns, then we might be tempted to say that when an agency decision is invalidated as arbitrary, it is not always because it is genuinely arbitrary. On the contrary, it may well be because the court would have preferred the 
agency to do otherwise. At least this is so when Republican appointees vote to strike down liberal decisions or those in Democratic administrations, and when Democratic appointees vote to strike down conservative decisions or those in Republican administrations.

Even here, however, it is necessary to be careful. Suppose that Republican appointees strike down liberal agency decisions at a much higher rate than conservative agency decisions. By itself, does this fact demonstrate bias? The answer is that it does not. Perhaps liberal agency decisions are especially likely to be arbitrary. And if Democratic appointees are peculiarly likely to strike down EPA decisions under Republican presidents, it may be because such decisions are indeed arbitrary. After finding an asymmetrical pattern of votes within any particular group of appointees, we might well be suspicious of ideological bias on the part of the judiciary. But no such suspicion has been vindicated by that kind of pattern.

The smoking gun, we think, is the see-saw pattern found in Table 1 - the fact that Republican validation rates jump from $58 \%$ to $72 \%$ when the agency decision becomes conservative, just as the Democratic validation rates fall from $71 \%$ to $56 \%$ when the agency decision becomes conservative. It cannot be the case that both camps are biasfree, simply responding to what any objective observer would deem arbitrary. The existence of ideological amplification sharpens this claim. If Democratic appointees show a greater rate of liberal voting when sitting with two Democratic appointees, and if Republican appointees show a greater rate of conservative voting when sitting with two Republican appointees, then something does seem seriously wrong.

To be sure, it is possible that one group is essentially neutral and right and that the other group is not. But it would be surprising if this possibility could be confirmed by an independent observer who was both neutral and right. The best conclusion is that in its operation, arbitrariness review is significantly affected by the ideological dispositions of federal judges, in a way that produces serious errors in light of the aspirations of State Farm itself. Recall that the most fundamental justification of hard look review is that with the grant of broad discretionary power to regulatory agencies, a firm judicial check is necessary as a kind of second-best substitute for insistence on the safeguards of the 
original constitutional system. ${ }^{116}$ If the consequence of that firm check is to give effect to the policy commitments of federal judges, the cure seems worse than the disease.

Notice, however, that our data show a large but not massive difference between Republican and Democratic appointees. It is not as if Republican appointees have a 10 percent validation rate when the agency decision is liberal and a 90 percent validation rate when the agency decision is conservative. On the contrary, Republican appointees vote to validate most liberal agency decisions, and Democratic appointees vote to validate most conservative agency decisions. A defender of the status quo, seeking to minimize the role of judicial policy preferences, might respond with the suggestion that the evidence is compatible with the view that State Farm has disciplined the judicial role, ensuring as it has that Republican and Democratic appointees generally agree with one another, and vote to validate agency decisions more often than whether they are coded as liberal or conservative.

We strongly agree with this suggestion insofar as it is meant to suggest that our data demonstrate that judicial ideology is not playing a dominant role, and that judicial policy choices are not driving arbitrariness review. A crudely "realist” picture of existing practice is wildly inconsistent with reality. Nonetheless, judicial policy preferences do play a significant role, and in the difficult cases, it does seem to be driving actual outcomes. Something is seriously amiss if Republican appointees are significantly more likely to uphold liberal agency decisions than conservative agency decisions and if Democratic appointees show the opposite pattern. We cannot rule out the possibility that one group has it essentially right, but it is not possible that both groups have it essentially right, and we suspect that errors can be found from both sides.

\section{Too Few Invalidations? Of Suspicion and Loyalty}

At this stage, politically motivated invalidations might seem to be the most serious problem. But a different reading of our findings is imaginable. Perhaps the problem is not that appointees of both parties vote, with some regularity, to invalidate decisions with which they might be expected to be unsympathetic. Perhaps the real problem is that appointees of both parties vote, with some regularity, to uphold the decisions of agencies

\footnotetext{
${ }^{116}$ For discussion, see Sunstein, supra note.
} 
with which they might be expected to be sympathetic. Perhaps the real problem, uncovered by our data, is not politically-driven suspicion but instead politically-driven loyalty or at least sympathy. On this view, what is most troubling, and what emerges as the real story here, is the high rates of validation, by judges nominated by a president of one or another party, of agency decisions which those judges might be expected to find agreeable.

Nothing in our data excludes this possibility. If the challenged agency decisions are often arbitrary, perhaps it is disturbing to see that Democratic appointees vote to uphold liberal decisions and that Republican appointees vote to uphold conservative decisions. Perhaps it is affirmatively desirable to find a high level of invalidations; perhaps the correct rulings are those by Republican appointees of liberal decisions, and by Democratic appointees of conservative decisions. In a world in which agency arbitrariness is pervasive, politically-driven validations would indeed be the problem.

Even if this is the correct reading of the data, and if validations rather than invalidations are the problem, the existing pattern of outcomes cannot be defended. If the real world of arbitrariness review includes a significant degree of political voting, leading to an unduly high validation rate, the appropriate correction is a "harder look," in the form of a general increase in judicial scrutiny. Moreover, we suspect that this is not the appropriate correction. If Democratic appointees are striking down conservative decisions at a higher rate than liberal decisions, and if Republican appointees are doing the same with liberal decisions, it would be surprising to find that all or most of the invalidated decisions are genuinely "arbitrary" within ordinary understandings of that term while also finding that the validated decisions are genuinely not "arbitrary." Most of the cases in our data involve complex questions of fact and value on which reasonable people can differ. But we do not deny the potential value of a more systematic inquiry into the possibility that politically-driven validations are a real problem.

\section{What Should Be Done? Of Decision Costs and Error Costs}

How do our findings bear on the continuing debate over arbitrariness review ${ }^{117}$ ? The first point is that questions about such review cannot be settled in the abstract.

\footnotetext{
${ }^{117}$ See, e.g., Mashaw and Harfst, supra note; Pierce, supra note; Breyer, supra note.
} 
Imagine, for example, a parallel world in which agency decisions are almost never arbitrary, and never especially harmful even when arbitrary. Imagine that in such a world, judicial review of arbitrariness would produce more, not less, in the way of arbitrariness, simply because judicial decisions are replete with bias and suffer from a lack of expertise and accountability. In that world, there is no point to arbitrariness review. By hypothesis, such review would make the situation worse rather than better. These are claims about the costs of errors; perhaps arbitrariness review increases those costs. At the same time, judicial review increases the costs of decisions, simply because it adds an additional layer, and possibly more than that, of decisional burdens on all sides.

Some people, in some periods, have believed that the United States is not so far from this imaginary world. ${ }^{118}$ At the very least, it is possible to find periods in which prominent voices suggest that aggressive judicial review of agency judgments of policy and fact is likely to cause serious problems. ${ }^{119}$ The New Deal period is a prominent example ${ }^{120}$; the same is true of the period after the election of President Reagan.

At the same time, we could easily imagine another and quite different parallel world, in which agency decisions are distinctly susceptible to the influences of selfinterested private groups, or otherwise a product of bias and confusion. In that world, we might also suppose that federal courts would provide an important ex post corrective and ex ante deterrent to biased and confused decisions. ${ }^{121}$ In such a world, stringent judicial review of agency judgments of fact and policy would be easy to defend.

We can identity prominent voices, in prominent periods, suggesting that this understanding is not so far from reality. ${ }^{122}$ The enactment of the Administrative Procedure Act was based on skepticism about agency bias and relative enthusiasm for judicial review. ${ }^{123}$ Indeed, the post-New Deal strengthening of substantial evidence review resulted from the Supreme Court's recognition of Congress' expression of a "mood" in favor of a more aggressive approach from the courts. ${ }^{124}$ The rise of the hard

\footnotetext{
${ }^{118}$ See Mashaw and Harsft, supra note.

${ }^{119}$ See, e.g., James Landis, The Administrative Process (1935); Mashaw and Harfst, supra note.

${ }^{120}$ See Stephen Breyer et al., Administrative Law and Regulatory Policy 18-20 (6 $6^{\text {th }}$ ed. 2006).

${ }^{121}$ See Pederson, supra note.

${ }^{122}$ See Leventhal, supra note.

${ }^{123}$ See Stephen Breyer et al., Administrative Law and Regulatory Policy 20-21 (6 ${ }^{\text {th }}$ ed. 2006); Universal Camera v. NLRB, 340 US 474 (1951).

${ }^{124}$ See Universal Camera, 340 US at XXX.
} 
look doctrine, in the 1960s and 1970s, was founded on similar assumptions about the value of judicial review in correcting agency errors and bias. ${ }^{125}$ Fearful of agency "capture," prominent judges defended the doctrine as a method for increasing agency accountability, by ensuring attention to the claims of a range of relevant interests, and also of promoting the application of technical expertise to difficult problems. ${ }^{126}$ For their part, skeptics pointed to the risk that hard look review would discourage agency rulemaking and reflect judicial bias on the merits. ${ }^{127}$

Our own findings demonstrate that judicial commitments are playing a significant role-and suggest the strong possibility that in many cases, judges are voting to invalidate agency decisions as arbitrary when they would not do so if their own predilections were otherwise. To the extent that this is so, there is a new argument for a softer look - that is, one that would ensure that agency decisions would be invalidated, as arbitrary, only when diverse judges could agree that they should be invalidated for that reason. We have a degree of confidence in the result when liberal decisions are invalidated by panels of RRR and RRD; we also have such confidence when conservative decisions are invalidated by panels of DDR or DDD. The troublesome cases involve invalidations that "fit" with the presumed ideology of the majority of judges on the relevant panel. ${ }^{128}$ And indeed, we have found disturbing patterns of that kind on the federal courts of appeals. But as we have acknowledged, it is also possible to be troubled by validations that fit with the presumed ideology of that same majority of judges. We might add that we have a degree of confidence in validations from DDR and DRR panels, and from DDD and RRR panels that are inconsistent with political expectations—-but that there is room for concern when an RRR panel upholds a conservative decisions and when a DDD panel upholds a liberal one.

It would therefore be possible to take our findings to support two different positions. The first is that judicial review should generally be weakened, so as to diminish the risk that invalidations reflect political commitments on the part of the relevant judges.

\footnotetext{
${ }^{125}$ See Sunstein, supra note.

${ }^{126}$ See Leventhal, supra note; see also the competing positions of Judges David Bazelon and Harold Leventhal in Ethyl Corp v EPA, 541 F2d 1 (DC Cir 1976) (en banc).

${ }^{127}$ See Melnick, supra note; Mashaw and Harfst, supra note.

${ }^{128}$ Cf. Frank Cross and Emerson Tiller, Judicial Partisanship and Legal Doctrine, 107 Yale LJ 2155 (1998) (finding that RRR panels show particular partisanship, in the predicted ideological direction, in a sample of Chevron cases).
} 
The second is that steps should be taken to reduce the risks associated with potentially partisan validations or invalidations - as, for example, when DDD panels regularly uphold liberal agency decisions, and when RRR panels show a special willingness to strike down such decisions. The second position seems to us more securely grounded in the evidence. It is certainly possible to fear that a general softening of judicial review would reduce a valuable ex post corrective and ex ante deterrent to arbitrary decisions-a fear to which our data do not speak.

Our findings also generate a clear prediction. When a judiciary dominated by the appointees of a Republican president reviews liberal agency decisions, or when a judiciary dominated by Democratic appointees reviews conservative agency decisions, the invalidation rate will increase. This prediction suggests that the debate over State Farm should consider the temporal effects of judicial policy preferences. The life tenure of federal judges implies that partisan imbalances in the appellate courts may persist for long periods. An unbalanced federal judiciary might well act as a brake on agencies' ability to implement the liberal or conservative policies of a new executive. ${ }^{129}$ The intensity of arbitrariness review can conspire with the life tenure of judges to make the effects of judicial ideology enduring.

It is not clear whether large-scale reforms are desirable. But several lessons do seem plain. At a minimum, the argument for Supreme Court review is strengthened in arbitrariness cases in which the outcome fits with the predicted ideological dispositions of unified panels. So too, those circumstances present unusually strong arguments for en banc review. A parallel lesson is more subtle and perhaps more important. If appellate judges are made aware that the evidence suggests a degree of ideological voting in arbitrariness review, perhaps that very awareness can operate as a kind of corrective or inoculation. In fact our hope is that an understanding of the data, on the part of lawyers and judges generally, might help to reduce the relevant effects in the future.

More generally, there might well be a fresh reason to revisit the current hard look, as a means of reducing the risk that agency decisions will be deemed arbitrary simply because judges do not agree with them on the merits. Remarkably, the Supreme Court has

\footnotetext{
${ }^{129}$ Cf. Adam B. Cox and Thomas J. Miles, Judging the Voting Rights Act, 107 Colum LR _ (forthcoming 2007) (arguing in the context of the pre-clearance procedures of Voting Rights Act that partisan influence in the Department of Justice may be more variable over time than judicial partisanship).
} 
issued no major pronouncements about arbitrariness review since State Farm itself. Its next encounter with the topic could provide a context for directing significant cautionary notes to the courts of appeals.

We could also imagine more dramatic responses. Here as elsewhere, there is reason to prefer mixed to unified panels, as a way of reducing the risk of ideologically driven outcomes. ${ }^{130}$ In an important context, Congress has made exactly this choice, ensuring that the independent agencies may have no more than a bare majority of commissioners from the same political party. ${ }^{131}$ For example, the National Labor Relations Board, the Federal Trade Commission, the Federal Communications Commission, and the Securities and Exchange Commission must have at least two Republican members (of five) under Democratic Presidents, and at least two Democratic members under Republican presidents. ${ }^{132}$ This requirement might well operate to reduce the risks of ideological outcomes that arise when adjudicative bodies are more unified. Note that the NLRB is one of our two principal agencies in the current study, and that the NLRB makes almost all of its law and policy through adjudication, construing the provisions of the National Labor Relations Act. ${ }^{133}$ It may be worth considering steps that would ensure mixed panels on appellate courts, at least in high-stakes cases involving review of agency decisions for arbitrariness.

A more ambitious plan would enlist voting rules-by, for example, requiring unanimous decisions for invalidation of agency rulings as arbitrary. ${ }^{134}$ We do not believe that our data support such a plan; the extent of ideological voting cannot justify such a dramatic departure from standard practices. But if unified panels are found, in the future, to show highly ideological voting patterns, it would be important to take steps to ensure that arbitrariness review does not amount, in practice, to Democratic or Republican review.

\footnotetext{
${ }^{130}$ Moin Yahya and James Stibopoulos, Does A Judge’s Party of Appointment or Gender Matter to Case Outcomes: An Empirical Study, Osgoode Hall LJ (2007); Cass R. Sunstein et al., Are Judges Political?, supra note.

${ }^{131}$ See, e.g., 15 USC 78d(a) (2000) (SEC).

132 Id.

133 The Board's famous tendency to avoid rulemaking is noticed, with an evident lack of enthusiasm, in Allentown Mack Sales and Service v. NLRB, 522 US 359 (1998).

${ }^{134}$ See Jacob E. Gersen and Adrian Vermeule, Chevron As A Voting Rule, 116 Yale LJ 676 (2007).
} 


\section{Conclusion}

In State Farm, the Supreme Court attempted to establish a framework that would check arbitrariness on the part of administrators who are often given broad discretionary authority. ${ }^{135}$ Our principal goal here has been to investigate the real world of arbitrariness review. We have found that the validation rate for the NLRB and the EPA is 64 percent. This rate is remarkably close to the validation rate for similar cases under Chevron.

The more important finding is that Democratic appointees show a far higher rate of liberal voting than do Republican appointees: $68 \%$ as opposed to 56\%. When agency decisions are liberal, Democratic appointees are far more likely to vote to uphold them than when they are conservative. By contrast, Republican appointees are far more likely to uphold conservative agency decisions than liberal agency decisions. Democratic appointees show especially liberal voting patterns when sitting on all-Democratic panels; Republican appointees show especially conservative voting patterns when sitting on allRepublican panels.

It follows that the political party of the appointing president is a fairly good predictor how a judge will vote in cases involving arbitrariness review; but the political party of the president who appointed the two other judges on the panel is also a strong predictor. These conclusions might be taken to provide fresh support for those who seek to soften arbitrariness review, or at least for those who seek to reduce the role of judicial policy preferences in review of agency action. The hard-look doctrine is most plausibly justified as a method for controlling the exercise of open-ended authority by regulatory agencies. To the extent that the doctrine operates, in practice, as a method of substituting judicial policy preferences for agency policy preferences, something is seriously wrong. Whether or not general softening is in order, steps might be taken to reduce that risk that judicial policy preferences are produced unjustified invalidations (and perhaps validations).

But our emphasis has been empirical, not normative. The differences between Republican and Democratic appointees are significant, but we have not found that

\footnotetext{
${ }^{135}$ Note that the National Traffic and Motor Vehicle Safety Act asks the Secretary of Transportation to issue standards that "shall be practicable, shall meet the need for motor vehicle safety, and shall be stated in objective terms." 15 USC 1392(a).
} 
judicial votes are politically driven. Recall that Republican appointees generally vote to validate liberal agency decisions and that Democratic appointees generally vote to validate conservative agency decisions. For this reason, it would be far too simple to say that the hard look is operationalized in purely political terms; our evidence is inconsistent with that conclusion. But it would not be too much to say that in important domains, the hard look is hardened, or softened, by the political predilections of federal judges. 
Figure 1.

Validation Rates of Circuit Judges in Arbitrariness Review Case, by Agency and by Party of Appointing President

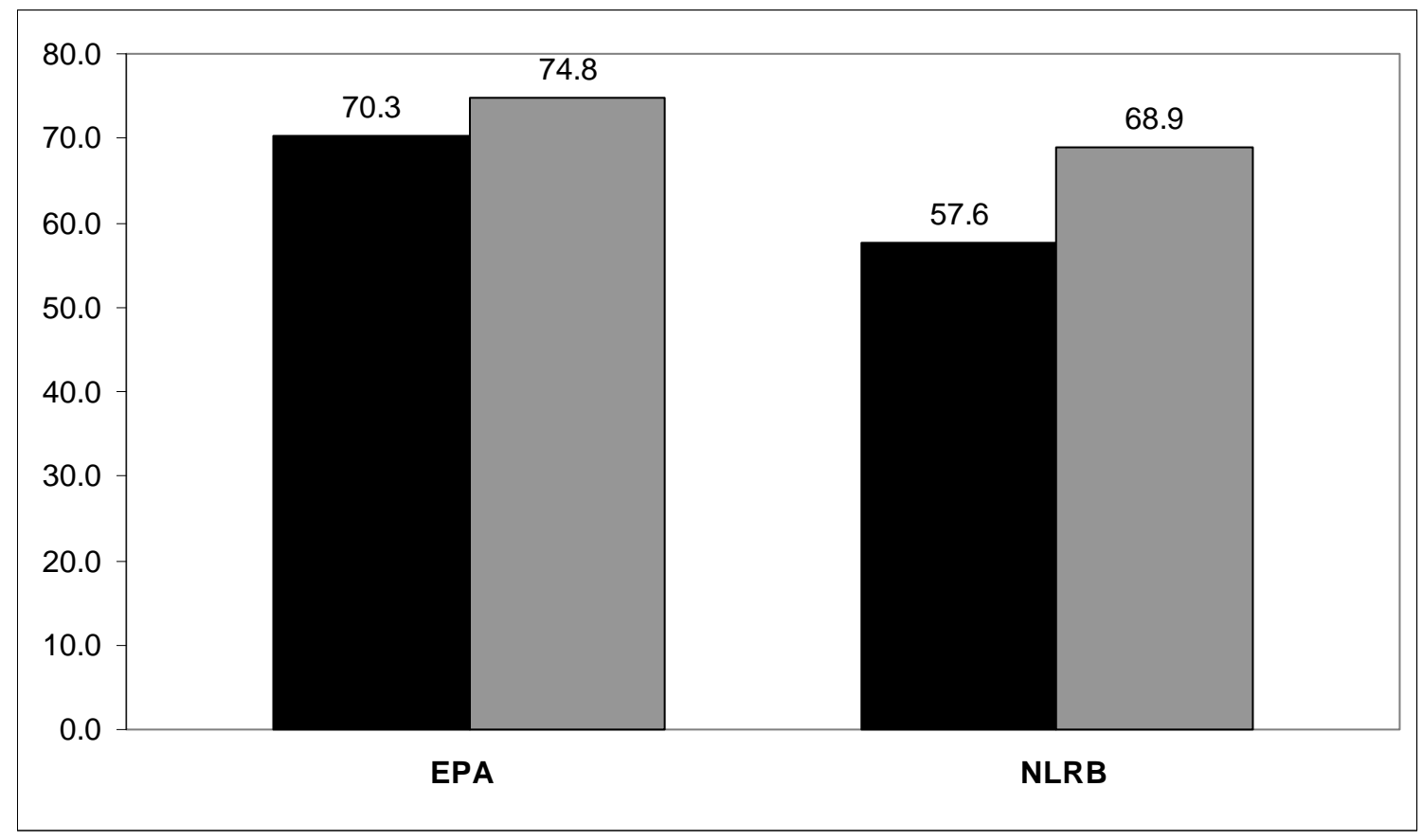

Note: The darkly shaded bars indicate the validation rates of Republican appointees, and the lightly shaded bars indicate the validation rates of Democratic appointees. 
Figure 2.

Validation Rates of Circuit Judges in Arbitrariness Review Case, by Panel Composition and by Party of Appointing President

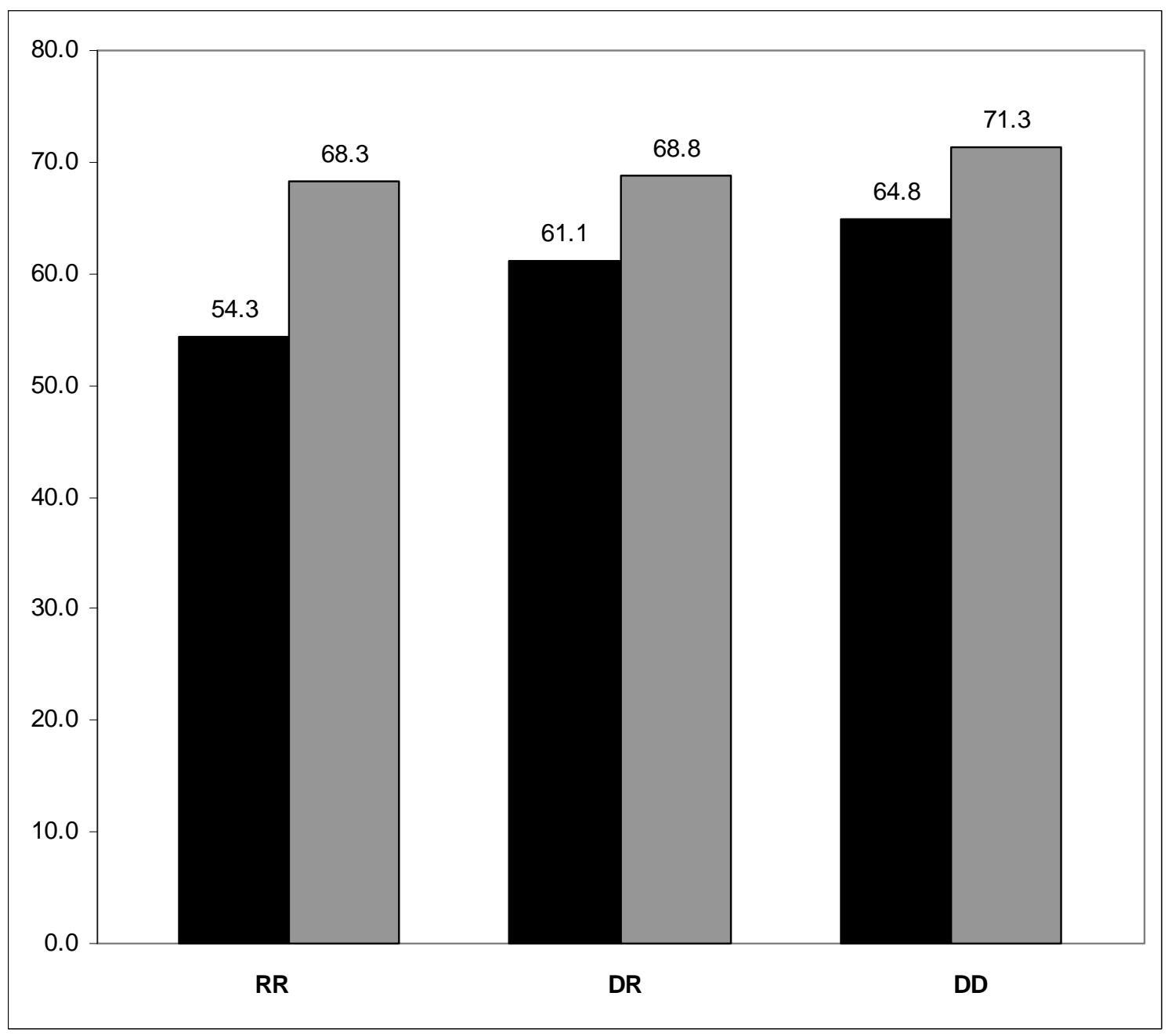

Note: The darkly shaded bars indicate the validation rates of Republican appointees, and the lightly shaded bars indicate the validation rates of Democratic appointees. 
Figure 3.

Liberal Voting Rates of Circuit Judges in Arbitrariness Review Case, by Panel Composition and by Party of Appointing President

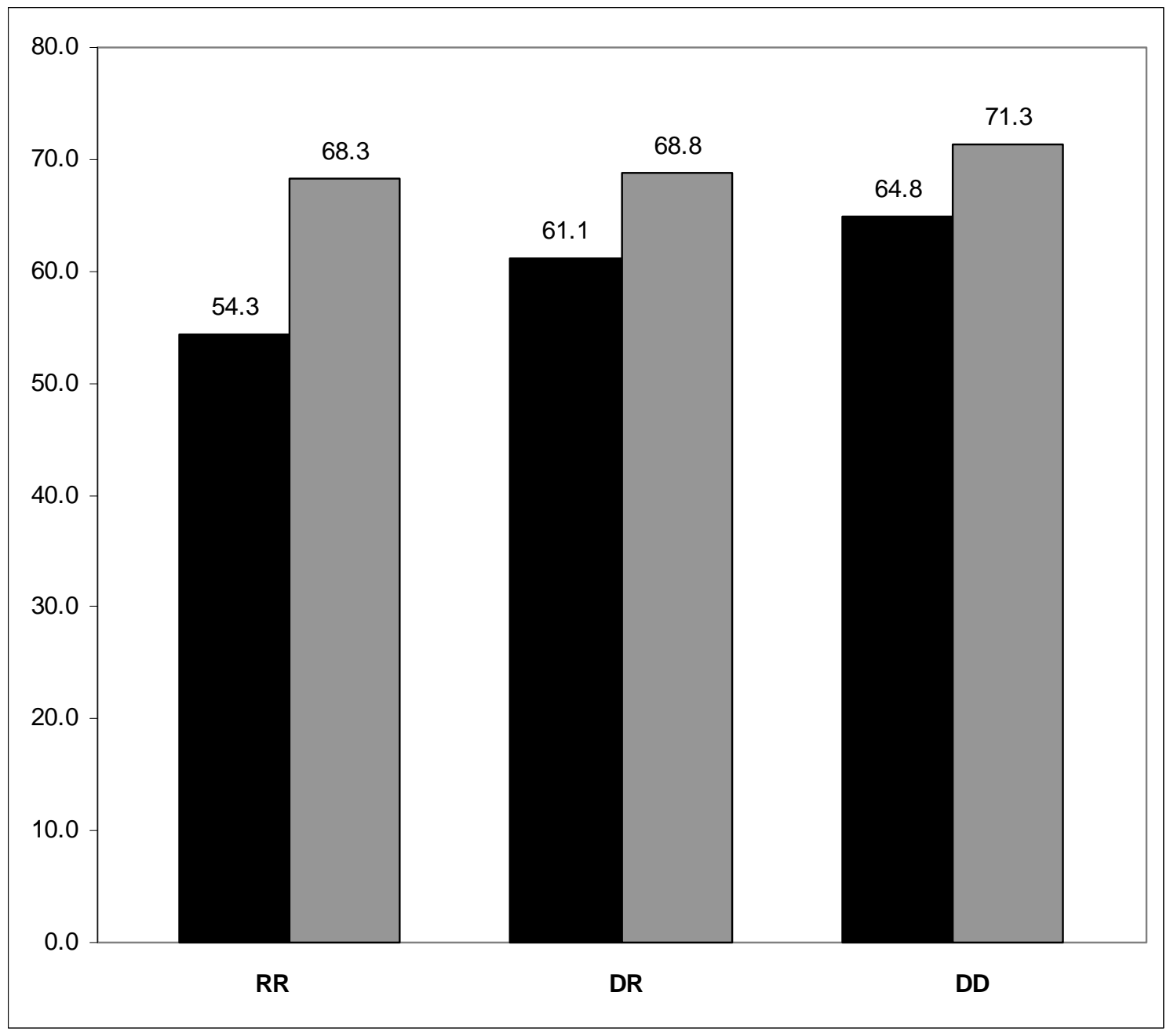

Note: The darkly shaded bars indicate the validation rates of Republican appointees, and the lightly shaded bars indicate the validation rates of Democratic appointees. 


\section{Table 1}

Validation Rates of Circuit Court Judges by Party of Appointing President in Arbitrariness Review Cases: Total and by Ideological Content of Agency Decision (Means, Standard Errors in Parentheses, and Number of Observations in Brackets)

\begin{tabular}{|c|c|c|c|c|}
\hline \multirow[b]{2}{*}{ Party of Appointing President } & \multirow[b]{2}{*}{$\begin{array}{c}\text { Total } \\
\text { (1) }\end{array}$} & \multicolumn{3}{|c|}{ Ideological Content of Agency Decision: } \\
\hline & & $\begin{array}{c}\text { Liberal } \\
(2)\end{array}$ & $\begin{array}{c}\text { Not Liberal } \\
(3)\end{array}$ & $\begin{array}{l}\text { Difference of } \\
(2)-(3):\end{array}$ \\
\hline (A) Democrat & $\begin{array}{c}.619 \\
(.016) \\
{[861]}\end{array}$ & $\begin{array}{c}.710 \\
(.017) \\
{[753]}\end{array}$ & $\begin{array}{c}.556 \\
(.048) \\
{[108]}\end{array}$ & $\begin{array}{c}.155^{* * *} \\
(.047)\end{array}$ \\
\hline (B) Republican & $\begin{array}{c}.597 \\
(.015) \\
{[1,098]}\end{array}$ & $\begin{array}{c}.584 \\
(.016) \\
{[987]}\end{array}$ & $\begin{array}{c}.721 \\
(.043) \\
{[111]}\end{array}$ & $\begin{array}{c}-.137 * * \\
(.049)\end{array}$ \\
\hline Difference of (A)-(B): & $\begin{array}{c}.094 * * * \\
(.022)\end{array}$ & $\begin{array}{c}.127^{* * *} \\
(.023)\end{array}$ & $\begin{array}{c}-.165^{* *} \\
(.064)\end{array}$ & -- \\
\hline
\end{tabular}

Note: * denotes difference significant at $10 \%$ level, ** denotes difference significant at $5 \%$ level, and *** denotes difference significant at $1 \%$ level. Differences may not match exactly due to rounding.

Table 2

Validation Rates of Circuit Court Judges

by Party of Appointing and Current President in Arbitrariness Review Cases. (Means, Standard Errors in Parentheses, and Number of Observations in Brackets)

\begin{tabular}{|c|c|c|c|c|}
\hline \multirow[b]{2}{*}{ Party of Appointing President } & \multirow[b]{2}{*}{$\begin{array}{l}\text { Total } \\
\text { (1) }\end{array}$} & \multicolumn{3}{|c|}{ Party of Current President: } \\
\hline & & $\begin{array}{c}\text { Democratic } \\
(2)\end{array}$ & $\begin{array}{c}\text { Republican } \\
\text { (3) }\end{array}$ & $\begin{array}{l}\text { Difference of } \\
(2)-(3):\end{array}$ \\
\hline (A) Democrat & $\begin{array}{c}.691 \\
(.016) \\
{[861]}\end{array}$ & $\begin{array}{l}.684 \\
(.024) \\
{[455]}\end{array}$ & $\begin{array}{l}.700 \\
(.023) \\
{[406]}\end{array}$ & $\begin{array}{l}-.016 \\
(.032)\end{array}$ \\
\hline (B) Republican & $\begin{array}{c}.597 \\
(.015) \\
{[1,098]}\end{array}$ & $\begin{array}{l}.565 \\
(.020) \\
{[589]}\end{array}$ & $\begin{array}{l}.635 \\
(.021) \\
{[509]}\end{array}$ & $\begin{array}{l}-.069 * * \\
(.030)\end{array}$ \\
\hline Difference of (A)—(B): & $\begin{array}{c}.094 * * * \\
(.022)\end{array}$ & $\begin{array}{l}.118 * * * \\
(.030)\end{array}$ & $\begin{array}{l}.065 * * \\
(.031)\end{array}$ & -- \\
\hline
\end{tabular}

Note: * denotes difference significant at 10\% level, ** denotes difference significant at 5\% level, and *** denotes difference significant at $1 \%$ level. Differences may not match exactly due to rounding. 
Table 3

Validation Rates in Arbitrariness Review Cases by Party of Appointing President, by Ideological Content of the Agency

Decision, and by Panel Composition (Means, Standard Errors in Parentheses, and Number of Observations in Brackets)

\begin{tabular}{|c|c|c|c|c|c|}
\hline \multirow[b]{2}{*}{ Party of Judge } & \multirow[b]{2}{*}{$\begin{array}{c}\text { Panel } \\
\text { Composition }\end{array}$} & \multirow[b]{2}{*}{$\begin{array}{c}\text { Total } \\
\text { (1) }\end{array}$} & \multicolumn{3}{|c|}{ Ideological Content of Agency Decision: } \\
\hline & & & $\begin{array}{c}\text { Liberal } \\
(2)\end{array}$ & $\begin{array}{c}\text { Not Liberal } \\
\text { (3) }\end{array}$ & $\begin{array}{l}\text { Difference of } \\
\text { (2) -(3): }\end{array}$ \\
\hline (A) Democrat & DDD & $\begin{array}{c}.713 \\
(.034) \\
{[174]}\end{array}$ & $\begin{array}{c}.748 \\
(.036) \\
{[147]}\end{array}$ & $\begin{array}{c}.519 \\
(.098) \\
{[27]}\end{array}$ & $\begin{array}{l}.230 * * \\
(.084)\end{array}$ \\
\hline (B) Democrat & $\begin{array}{l}\text { DDR or } \\
\text { RRD }\end{array}$ & $\begin{array}{c}.686 \\
(.018) \\
{[687]}\end{array}$ & $\begin{array}{c}.701 \\
(.019) \\
{[606]}\end{array}$ & $\begin{array}{c}.568 \\
(.055) \\
{[81]}\end{array}$ & $\begin{array}{l}.133^{* *} \\
(.055)\end{array}$ \\
\hline ( C) Republican & $\begin{array}{l}\text { DDR or } \\
\text { RRD }\end{array}$ & $\begin{array}{c}.620 \\
(.017) \\
{[772]}\end{array}$ & $\begin{array}{l}.612 \\
(.019) \\
{[691]}\end{array}$ & $\begin{array}{c}.691 \\
(.052) \\
{[81]}\end{array}$ & $\begin{array}{c}-.079 \\
(.057)\end{array}$ \\
\hline (D) Republican & RRR & $\begin{array}{c}.543 \\
(.028) \\
{[326]}\end{array}$ & $\begin{array}{c}.517 \\
(.029) \\
{[296]}\end{array}$ & $\begin{array}{c}.800 \\
(.074) \\
{[30]}\end{array}$ & $\begin{array}{c}-.283^{* *} \\
(.094)\end{array}$ \\
\hline Difference of $(A)-(B)$ : & -- & $\begin{array}{c}.027 \\
(.039)\end{array}$ & $\begin{array}{l}.047 \\
(.042)\end{array}$ & $\begin{array}{c}.049 \\
(.111)\end{array}$ & -- \\
\hline Difference of $(A)-(C)$ : & -- & $\begin{array}{c}.092 * * \\
(.040)\end{array}$ & $\begin{array}{l}.136 * * \\
(.043)\end{array}$ & $\begin{array}{l}-.173^{*} \\
(.106)\end{array}$ & -- \\
\hline Difference of (A)-(D): & -- & $\begin{array}{c}.170 * * \\
(.045)\end{array}$ & $\begin{array}{c}.231 * * * \\
(.048)\end{array}$ & $\begin{array}{c}-.281 * * \\
(.122)\end{array}$ & -- \\
\hline Difference of (B)-( C): & -- & $\begin{array}{c}.065^{* *} \\
(.025)\end{array}$ & $\begin{array}{c}.089 * * * \\
(.026)\end{array}$ & $\begin{array}{l}-.123 * \\
(.076)\end{array}$ & -- \\
\hline Difference of (B)—(D): & -- & $\begin{array}{c}.143^{* * *} \\
(.032)\end{array}$ & $\begin{array}{c}.184 * * * \\
(.033)\end{array}$ & $\begin{array}{l}.232 * * \\
(.107)\end{array}$ & -- \\
\hline Difference of ( C)-(D): & -- & $\begin{array}{l}.078 * * \\
(.032)\end{array}$ & $\begin{array}{l}.095 * * \\
(.034)\end{array}$ & $\begin{array}{l}.107 \\
(.096)\end{array}$ & -- \\
\hline
\end{tabular}

Note: * denotes difference significant at $10 \%$ level, $* *$ denotes difference significant at $5 \%$ level, and $* * *$ denotes difference significant at $1 \%$ level. 
Table 4

Liberal Vote Rates of Circuit Court Appointees by

Party of Appointing and Current President in Arbitrariness Review Cases.

(Means, Standard Errors in Parentheses, and Number of Observations in Brackets)

\begin{tabular}{|c|c|c|c|c|}
\hline \multirow[b]{2}{*}{ Judge’s Party: } & \multirow[b]{2}{*}{$\begin{array}{l}\text { Total } \\
\text { (1) }\end{array}$} & \multicolumn{2}{|c|}{ President's Party: } & \multirow[b]{2}{*}{$\begin{array}{l}\text { Difference of } \\
\text { (2) - (3): }\end{array}$} \\
\hline & & $\begin{array}{c}\text { Democratic } \\
(2)\end{array}$ & $\begin{array}{c}\text { Republican } \\
\text { (3) }\end{array}$ & \\
\hline (A) Democrat & $\begin{array}{c}.677 \\
(.016)\end{array}$ & $\begin{array}{c}.648 \\
(.022) \\
\end{array}$ & $\begin{array}{c}.709 \\
(.023)\end{array}$ & $\begin{array}{c}-.061 * \\
(.032)\end{array}$ \\
\hline & [861] & [455] & [406] & \\
\hline (B) Republican & $\begin{array}{c}.553 \\
(.015) \\
{[1,098]}\end{array}$ & $\begin{array}{l}.526 \\
(.021) \\
{[589]}\end{array}$ & $\begin{array}{c}.583 \\
(.022) \\
{[509]}\end{array}$ & $\begin{array}{l}-.057 * \\
(.030)\end{array}$ \\
\hline $\begin{array}{l}\text { Difference of } \\
\text { (A)-(B): }\end{array}$ & $\begin{array}{c}.124 * * * \\
(.022)\end{array}$ & $\begin{array}{l}.122 * * * \\
(.031)\end{array}$ & $\begin{array}{l}.126 * * * \\
(.032)\end{array}$ & -- \\
\hline
\end{tabular}

Note: * denotes difference significant at 10\% level, ** denotes difference significant at 5\% level, and *** denotes difference significant at $1 \%$ level. Differences may not match exactly due to rounding.

Table 5

Validation Rates in Arbitrariness Review Cases by Party of Appointing President and Circuit

(Means, Standard Errors in Parentheses, and Number of Observations in Brackets)

\begin{tabular}{|c|c|c|c|}
\hline \multirow[b]{2}{*}{ Party of Appointing President } & \multicolumn{3}{|c|}{ Circuit Court of Appeals: } \\
\hline & $\begin{array}{l}\text { District of } \\
\text { Columbia } \\
\text { (2) }\end{array}$ & $\begin{array}{c}\text { All Other } \\
\text { Circuits } \\
\text { (3) }\end{array}$ & $\begin{array}{l}\text { Difference of } \\
\text { (2) -(3): }\end{array}$ \\
\hline (A) Democrat & $\begin{array}{c}.622 \\
(.029) \\
{[286]}\end{array}$ & $\begin{array}{c}.725 \\
(.019) \\
{[575]}\end{array}$ & $\begin{array}{l}-.067 * \\
(.034)\end{array}$ \\
\hline (B) Republican & $\begin{array}{c}.547 \\
(.030) \\
{[274]}\end{array}$ & $\begin{array}{c}.614 \\
(.017) \\
{[824]}\end{array}$ & $\begin{array}{c}-.103 * * \\
(.033)\end{array}$ \\
\hline Difference of (A)-(B): & $\begin{array}{l}.075 * \\
(.042)\end{array}$ & $\begin{array}{c}.111^{* * * *} \\
(.026)\end{array}$ & -- \\
\hline
\end{tabular}

Note: * denotes difference significant at $10 \%$ level, ** denotes difference significant at $5 \%$ level, and *** denotes difference significant at $1 \%$ level. Differences may not match exactly due to rounding. 


\section{Table 6}

Validation Rates in Arbitrariness Review Cases by Party of Appointing President, Ideological Content of Agency Decision, and Circuit (Means, Standard Errors in Parentheses, and Number of Observations in Brackets)

A. Circuit Court of Appeals for the District of Columbia

\begin{tabular}{lccc}
\hline \hline & \multicolumn{3}{c}{ Ideological Content of Agency Decision: } \\
\cline { 2 - 4 } Party of Appointing President & Liberal & Not Liberal & $\begin{array}{c}\text { Difference of } \\
(2)-(3):\end{array}$ \\
\hline (A) Democrat & $(2)$ & .676 & $\mathbf{. 0 6 2}$ \\
& $(.031)$ & $(.085)$ & $\mathbf{( . 0 9 2 )}$ \\
& {$[255]$} & {$[31]$} & \\
(B) Republican & .525 & .719 & $\mathbf{- . 1 9 4 * *}$ \\
& $(.032)$ & $(.081)$ & $\mathbf{( . 0 9 3 )}$ \\
Difference of (A)-(B): & {$[242]$} & {$[32]$} & \\
& & & - \\
& $\mathbf{. 0 9 1 * *}$ & $\mathbf{- . 0 4 1}$ & - \\
\hline
\end{tabular}

B. Other Circuit Courts of Appeals

\begin{tabular}{|c|c|c|c|}
\hline \multirow[b]{2}{*}{ Party of Appointing President } & \multicolumn{3}{|c|}{ Ideological Content of Agency Decision: } \\
\hline & $\begin{array}{l}\text { Liberal } \\
\text { (2) }\end{array}$ & $\begin{array}{l}\text { Not Liberal } \\
\text { (3) }\end{array}$ & $\begin{array}{l}\text { Difference of } \\
\text { (2) -(3): }\end{array}$ \\
\hline (A) Democrat & $\begin{array}{c}.759 \\
(.019) \\
{[498]}\end{array}$ & $\begin{array}{c}.506 \\
(.057) \\
{[77]}\end{array}$ & $\begin{array}{c}.253^{* * * *} \\
(.054)\end{array}$ \\
\hline (B) Republican & $\begin{array}{c}.603 \\
(.018) \\
{[745]}\end{array}$ & $\begin{array}{c}.722 \\
(.051) \\
{[79]}\end{array}$ & $\begin{array}{l}-.119 * * \\
(.058)\end{array}$ \\
\hline Difference of (A)-(B): & $\begin{array}{c}.156 * * * \\
(.027)\end{array}$ & $\begin{array}{l}-.215 * * \\
(.076)\end{array}$ & -- \\
\hline
\end{tabular}

Note: * denotes difference significant at $10 \%$ level, ** denotes difference significant at $5 \%$ level, and $* * *$ denotes difference significant at $1 \%$ level. Differences may not match exactly due to rounding. 
Table 7

Liberal Voting Rates in Arbitrariness Review Cases by Party of Appointing President and Circuit

(Means, Standard Errors in Parentheses, and Number of Observations in Brackets)

\begin{tabular}{lccc}
\hline \hline & \multicolumn{4}{c}{ Circuit Court of Appeals: } \\
\cline { 2 - 4 } Party of Appointing President & $\begin{array}{c}\text { District of } \\
\text { Columbia } \\
(2)\end{array}$ & $\begin{array}{c}\text { All Other } \\
\text { Circuits }\end{array}$ & $\begin{array}{c}\text { Difference of } \\
(2)-(3):\end{array}$ \\
\hline (A) Democrat & .584 & .723 & $\mathbf{. 1 4 0 * * *}$ \\
& $(.029)$ & $(.019)$ & $\mathbf{( . 0 3 4 )}$ \\
& {$[286]$} & {$[575]$} & \\
(B) Republican & .496 & .572 & $\mathbf{. 0 7 5 * *}$ \\
& $(.030)$ & $(.017)$ & $\mathbf{( . 0 3 5 )}$ \\
Difference of (A)-(B): & {$[274]$} & {$[824]$} & \\
& & & - \\
& $\mathbf{. 0 8 8 * *}$ & $\mathbf{. 1 5 2 * *}$ & \\
\hline
\end{tabular}

Note: * denotes difference significant at $10 \%$ level, ** denotes difference significant at $5 \%$ level, and *** denotes difference significant at $1 \%$ level. Differences may not match exactly due to rounding.

Table 8

Effects of Reduced Intensity of Judicial Review on Validation Rates

\begin{tabular}{lll}
\hline \multirow{2}{*}{ Are the Litigants Responsive? } & \multicolumn{2}{c}{ Is the Agency Responsive? } \\
\cline { 2 - 3 } Yes & \multicolumn{1}{c}{ Yes } & \multicolumn{1}{c}{ No } \\
Nolidation rate & $\begin{array}{l}\text { No change (or lower } \\
\text { validation rate) }\end{array}$ \\
No & $\begin{array}{l}\text { No change (or lower } \\
\text { validation rate) }\end{array}$ & Higher validation rate \\
& & \\
\hline
\end{tabular}


Readers with comments should address them to:

\section{Professor Cass Sunstein}

University of Chicago Law School

1111 East 60th Street

Chicago, IL 60637

csunstei@midway.uchicago.edu 


\section{Chicago Working Papers in Law and Economics (Second Series)}

For a listing of papers 1-299 please go to Working Papers at http://www.law.uchicago.edu/Lawecon/index.html

300. Adam B. Cox, The Temporal Dimension of Voting Rights (July 2006)

301. Adam B. Cox, Designing Redistricting Institutions (July 2006)

302. Cass R. Sunstein, Montreal vs. Kyoto: A Tale of Two Protocols (August 2006)

303. Kenneth W. Dam, Legal Institutions, Legal Origins, and Governance (August 2006)

304. Anup Malani and Eric A. Posner, The Case for For-Profit Charities (September 2006)

305. Douglas Lichtman, Irreparable Benefits (September 2006)

306. M. Todd Henderson, Paying CEOs in Bankruptcy: Executive Compensation when Agency Costs Are Low (September 2006)

307. Michael Abramowicz and M. Todd Henderson, Prediction Markets for Corporate Governance (September 2006)

308. Randal C. Picker, Who Should Regulate Entry into IPTV and Municipal Wireless? (September 2006)

309. Eric A. Posner and Adrian Vermeule, The Credible Executive (September 2006)

310. David Gilo and Ariel Porat, The Unconventional Uses of Transaction Costs (October 2006)

311. Randal C. Picker, Review of Hovenkamp, The Antitrust Enterprise: Principle and Execution (October 2006)

312. Dennis W. Carlton and Randal C. Picker, Antitrust and Regulation (October 2006)

313. Robert Cooter and Ariel Porat, Liability Externalities and Mandatory Choices: Should Doctors Pay Less? (November 2006)

314. Adam B. Cox and Eric A. Posner, The Second-Order Structure of Immigration Law (November 2006)

315. Lior J. Strahilevitz, Wealth without Markets? (November 2006)

316. Ariel Porat, Offsetting Risks (November 2006)

317. Bernard E. Harcourt and Jens Ludwig, Reefer Madness: Broken Windows Policing and Misdemeanor Marijuana Arrests in New York City, 1989-2000 (December 2006)

318. Bernard E. Harcourt, Embracing Chance: Post-Modern Meditations on Punishment (December 2006)

319. Cass R. Sunstein, Second-Order Perfectionism (December 2006)

320. William M. Landes and Richard A. Posner, The Economics of Presidential Pardons and Commutations (January 2007)

321. Cass R. Sunstein, Deliberating Groups versus Prediction Markets (or Hayek’s Challenge to Habermas) (January 2007)

322. Cass R. Sunstein, Completely Theorized Agreements in Constitutional Law (January 2007)

323. Albert H. Choi and Eric A. Posner, A Critique of the Odious Debt Doctrine (January 2007)

324. Wayne Hsiung and Cass R. Sunstein, Climate Change and Animals (January 2007)

325. Cass. R. Sunstein, Cost-Benefit Analysis without Analyzing Costs or Benefits: Reasonable Accommodation, Balancing and Stigmatic Harms (January 2007)

326. Cass R. Sunstein, Willingness to Pay versus Welfare (January 2007)

327. David A. Weisbach, The Irreducible Complexity of Firm-Level Income Taxes: Theory and Doctrine in the Corporate Tax (January 2007)

328. Randal C. Picker, Of Pirates and Puffy Shirts: A Comments on "The Piracy Paradox: Innovation and Intellectual Property in Fashion Design” (January 2007)

329. Eric A. Posner, Climate Change and International Human Rights Litigation: A Critical Appraisal (January 2007)

330. Randal C. Picker, Pulling a Rabbi Out of His Hat: The Bankruptcy Magic of Dick Posner (February 2007)

331. Bernard E. Harcourt, Judge Richard Posner on Civil Liberties: Pragmatic (Libertarian) Authoritarian (February 2007) 
332. Cass R. Sunstein, If People Would Be Outraged by Their Rulings, Should Judges Care? (February 2007)

333. Eugene Kontorovich, What Standing Is Good For (March 2007)

334. Eugene Kontorovich, Inefficient Customs in International Law (March 2007)

335. Bernard E. Harcourt, From the Asylum to the Prison: Rethinking the Incarceration Revolution. Part II: State Level Analysis (March 2007)

336. Cass R. Sunstein, Due Process Traditionalism (March 2007)

337. Adam B. Cox and Thomas J. Miles, Judging the Voting Rights Act (March 2007)

338. M. Todd Henderson, Deconstructing Duff \& Phelps (March 2007)

339. Douglas G. Baird and Robert K. Rasmussen, The Prime Directive (April 2007)

340. $\quad$ Cass R. Sunstein, Illusory Losses (May 2007)

341. Anup Malani, Valuing Laws as Local Amenities (June 2007)

342. David A. Weisbach, What Does Happiness Research Tell Us about Taxation? (June 2007)

343. David S. Abrams and Chris Rohlfs, Optimal Bail and the Value of Freedom: Evidence from the Philadelphia Bail Experiment (June 2007)

344. Christopher R. Berry and Jacob E. Gersen, The Fiscal Consequences of Electoral Institutions (June 2007)

345. Matthew Adler and Eric A. Posners, Happiness Research and Cost-Benefit Analysis (July 2007)

346. Daniel Kahneman and Cass R. Sunstein, Indignation: Psychology, Politics, Law (July 2007)

347. Jacob E. Gersen and Eric A. Posner, Timing Rules and Legal Institutions (July 2007)

348. $\quad$ Eric A. Posner and Adrian Vermeule, Constitutional Showdowns (July 2007)

349. Lior Jacob Strahilevitz, Privacy versus Antidiscrimination (July 2007)

350. Bernard E. Harcourt, A Reader's Companion to Against Prediction: A Reply to Ariela Gross, Yoram Margalioth, and Yoav Sapir on Economic Modeling, Selective Incapacitation, Governmentality, and Race (July 2007)

351. Lior Jacob Strahilevitz, “Don’t Try This at Home”: Posner as Political Economist (July 2007)

352. Cass R. Sunstein, The Complex Climate Change Incentives of China and the United States (August 2007)

353. David S. Abrams and Marianne Bertrand, Do Judges Vary in Their Treatment of Race? (August 2007)

354. Eric A. Posner and Cass R. Sunstein, Climate Change Justice (August 2007)

355. David A. Weisbach, A Welfarist Approach to Disabilities (August 2007)

356. David S. Abrams, More Time, Less Crime? Estimating the Deterrent Effect of Incarceration using Sentencing Enhancements (August 2007)

357. Stephen J. Choi, G. Mitu Gulati and Eric A. Posner, Professionals or Politicians: The Uncertain Empirical Case for an Elected Rather than Appointed Judiciary (August 2007)

358. Joseph Bankman and David A. Weisbach, Consuption Taxation Is Still Superior to Income Taxation (September 2007)

359. Dougals G. Baird and M. Todd Henderson, Other People’s Money (September 2007)

360. William Meadow and Cass R. Sunstein, Causation in Tort: General Populations vs. Individual Cases (September 2007)

361. Richard McAdams and Janice Nadler, Coordinating in the Shadow of the Law: Two Contextualized Tests of the Focal Point Theory of Legal Compliance (September 2007)

362. Richard McAdams, Reforming Entrapment Doctrine in United States v. Hollingsworth (September 2007)

363. M. Todd Henderson, From Seriatim to Consensus and Back Again: A Theory of Dissent (October 2007)

364. Timur Kuran and Cass R. Sunstein, Availability Cascades and Risk Regulation (October 2007)

365. David A. Weisbach, The Taxation of Carried Interests in Private Equity (October 2007)

366. $\quad$ Lee Anne Fennell, Homeownership 2.0 (October 2007)

367. Jonathan R. Nash and Rafael I. Pardo, An Empirical Investigation into Appellate Structure and the Perceived Quality of Appellate Review (October 2007)

368. Thomas J. Miles and Cass R. Sunstein, The Real World of Arbitrariness Review (November 2007) 